Setyan, A.; Sauvain, J.J.; Riediker, M.; Guillemin, M. and Rossi, M.J. Characterization of surface functional groups present on laboratory-generated and ambient aerosol particles by means of heterogeneous titration reactions. Journal of Aerosol Science 2009, 40(6):534-548.

\begin{tabular}{|l|l|}
\hline Postprint version & Final draft post-refereeing \\
\hline Journal website & http://www.sciencedirect.com/science/journal/00218502 \\
\hline DOI & $10.1016 /$ j.jaerosci.2009.01.008 \\
\hline
\end{tabular}




\title{
Characterization of surface functional groups present on laboratory-generated and ambient aerosol particles by means of heterogeneous titration reactions
}

\author{
Ari Setyan ${ }^{\mathrm{a}}$, Jean-Jacques Sauvain ${ }^{\mathrm{a}}$, Michael Riediker ${ }^{\mathrm{a}}$, Michel Guillemin ${ }^{\mathrm{a}}$, Michel J. Rossi ${ }^{\mathrm{b}}$ \\ ${ }^{\text {a }}$ Institute for Work and Health, University of Lausanne and University of Geneva, Rue du \\ Bugnon 21, CH-1011 Lausanne, Switzerland \\ ${ }^{\mathrm{b}}$ Swiss Federal Institute of Technology, Air and Soil Pollution Laboratory, Station 6, CH- \\ 1015 Lausanne, Switzerland
}

\section{Corresponding author}

Michel J. Rossi

Paul Scherrer Institut

Labor für Atmosphärenchemie

OFLA 008

$\mathrm{CH}$ - 5232 Villigen PSI

Switzerland

Phone: +41563105259

Fax: $\quad+41563104525$

e-mail: michel.rossi@psi.ch

\section{E-mails of co-authors}

ari.setyan@gmail.com

jean-jacques.sauvain@hospvd.ch

michael.riediker@hospvd.ch

michel.guillemin@tvtmail.ch 


\begin{abstract}
A Knudsen flow reactor has been used to quantify surface functional groups on aerosols collected in the field. This technique is based on a heterogeneous titration reaction between a probe gas and a specific functional group on the particle surface. In the first part of this work, the reactivity of different probe gases on laboratory-generated aerosols (limonene SOA, $\left.\mathrm{Pb}\left(\mathrm{NO}_{3}\right)_{2}, \mathrm{Cd}\left(\mathrm{NO}_{3}\right)_{2}\right)$ and Diesel reference soot (SRM 2975) has been studied. Five probe gases have been selected for the quantitative determination of important functional groups: $\mathrm{N}\left(\mathrm{CH}_{3}\right)_{3}$ (for the titration of acidic sites), $\mathrm{NH}_{2} \mathrm{OH}$ (for carbonyl functions), $\mathrm{CF}_{3} \mathrm{COOH}$ and $\mathrm{HCl}$ (for basic sites of different strength), $\mathrm{O}_{3}$ (for oxidizable groups). The second part describes a field campaign that has been undertaken in several bus depots in Switzerland, where ambient fine and ultrafine particles were collected on suitable filters and quantitatively investigated using the Knudsen flow reactor. Results point to important differences in the surface reactivity of ambient particles, depending on the sampling site and season. The particle surface appears to be multi-functional, with the simultaneous presence of antagonistic functional groups which do not undergo internal chemical reactions, such as acid-base neutralization. Results also indicate that the surface of ambient particles was characterized by a high density of carbonyl functions (reactivity towards $\mathrm{NH}_{2} \mathrm{OH}$ probe in the range 0.26 to 6 formal molecular monolayers) and a low density of acidic sites (reactivity towards $\mathrm{N}\left(\mathrm{CH}_{3}\right)_{3}$ probe in the range 0.01 to 0.20 formal molecular monolayer). Kinetic parameters point to fast redox reactions (uptake coefficient $\gamma_{0}>10^{-3}$ for $\mathrm{O}_{3}$ probe) and slow acid-base reactions $\left(\gamma_{0}<\right.$ $10^{-4}$ for $\mathrm{N}\left(\mathrm{CH}_{3}\right)_{3}$ probe) on the particle surface.
\end{abstract}

\title{
Keywords
}

$\mathrm{PM}_{4}$, surface reactivity, heterogeneous reaction, Knudsen flow reactor, field measurement 


\section{Introduction}

The presence of anthropogenic particulate matter in the atmosphere is nowadays considered to be a major environmental problem. Indeed, exposure to $\mathrm{PM}_{10}$ and $\mathrm{PM}_{2.5}$ (particulate matter with an aerodynamic diameter smaller than 10 and $2.5 \mu \mathrm{m}$, respectively) is associated with a range of adverse health effects, including cancer (Bhatia et al., 1998), respiratory (Neuberger et al., 2004) and cardiovascular (Pope et al., 2004) diseases. So far, several mechanisms have been proposed to explain harmful effects of particulate matter. According to the most probable hypotheses, particle surface characteristics (chemical reactivity, surface area) are of prime importance for the understanding of the toxicity of particulate matter (Brown et al., 2001). Surface chemistry is important, because it controls the molecular and cellular interactions with the critical parts of the respiratory-tract components, such as lung lining fluid and different cells (Kendall et al., 2004a). Therefore, physico-chemical characteristics of the particle surface impacting the lung may affect the initial physiological responses, and thus control the downstream effects. For instance, the presence of several components adsorbed on particles, such as metal ions (Park et al., 2006) and organics (Mauderly and Chow, 2008), has been found to generate Reactive Oxygen Species (ROS), and thereby to cause oxidative stress in biological systems.

Moreover, particles are involved in atmospheric processes, and suspected to play a role in global climate change (Finlayson-Pitts and Pitts, 2000). They are able to scatter incoming solar radiation and, in some cases, to absorb it as well, converting absorbed energy to heat, and therefore contributing to the warming of the troposphere. Particles are also involved in the formation of clouds, and may affect the concentration of atmospheric trace gases by heterogeneous chemical reactions (Cwiertny et al., 2008).

Over the past 10 years, great efforts have been placed onto the surface characterization of particulate matter. So far, experiments have been carried out mainly by means of different spectroscopic methods. X-ray Photoelectron Spectroscopy (XPS; Qi et al., 2006), Fourier Transform Infra-Red (FT-IR; Fermo et al., 2006) and Raman (Sze et al., 2001) have been often used to investigate carbonaceous and inorganic particles, but these techniques do not focus exclusively on the gas-particle interface. Near-Edge X-ray Absorption Fine Structure (NEXAFS) spectroscopy is an emerging tool in the surface characterization of carbonaceous particles (Braun, 2005). C (1s) NEXAFS spectra have the advantage to present molecular fingerprints allowing to distinguish various kinds of carbonaceous particles, such as graphite 
or Diesel soot. Electron Energy Loss Spectroscopy (EELS) is a related technique which has been widely used in the analysis of carbonaceous particles (Chen et al., 2005), often in association with Transmission Electron Microscopy (TEM). However, these electron spectroscopies are hampered by low to modest energy resolution as well as a limited sensitivity for surface species.

The Knudsen flow reactor represents an alternative technique that allows the characterization of surface functional groups present on particles at a high sensitivity, typically in the range of $1 \%$ of a formal molecular monolayer. This method is based on a heterogeneous chemical reaction between a gas-phase probe molecule and a specific functional group on the surface of a sample. Over the past 15 years, this technique has been used especially in the field of atmospheric chemistry. Heterogeneous reactions have been investigated on different types of particle surrogates, such as soot (Stadler and Rossi, 2000), mineral dust (Ullerstam et al., 2003; Karagulian and Rossi, 2005) or sea salt (Rossi, 2003). Even if the present titration reactions are undertaken in the gas-phase, we surmise that the particle surface composition will not significantly change when the particle is immersed into a liquid, such that the results of the present approach may still give useful clues for solution studies. An advantage of this technique over spectroscopic methods is that kinetic data and the identification of reaction products may be obtained. On the other hand, the identification of surface functional groups is indirect and afforded by the chemical reactivity of the surface in terms of surface composition. The results may be difficult to interpret because of several possible competing reactions.

The aim of the present research was to use the Knudsen flow reactor technique to measure functional groups present on the surface of particles sampled in occupational situations. A study was first undertaken to test the reactivity of several probe gases towards laboratorygenerated aerosols. Preliminary work was already performed in our laboratory by Demirdjian and Rossi (2005), who tested the reactivity of four probe gases towards several laboratorygenerated aerosols. We have extended this work in order to find other probe gases allowing the quantification of additional functional groups present on the particle surface, especially those which are suspected to play a role in adverse health effects of particulate matter (metal ions, acids). In the second part of the study, we sampled ambient fine and ultrafine particles in several bus depots in Switzerland, and investigated surface functional groups of these samples. The kinetics of titration reactions were also measured to obtain further information on the reactivity of particulate matter. 


\section{Material and methods}

\subsection{Knudsen flow reactor}

The Knudsen flow reactor has previously been described in detail in the literature (Caloz et al., 1997). Briefly, this technique is used for the study of heterogeneous chemical reactions between a gas-phase probe molecule and a solid-phase sample. For each type of functional group present on the aerosol surface (such as carbonyl, acidic, basic, or oxidizable groups), the interaction of a suitable titrant molecule with the aerosol is studied. The type and number of probe molecules taken up by the sample, whose mass and surface area have previously been measured, reveals the identity and number of functional groups present on the surface of the sample.

The experimental setup of the Knudsen flow reactor is shown in Figure 1, the parameter setting in Table 1 and a typical raw data of a titration experiment in Figure 2. The background pressure in the reactor is maintained between $10^{-6}$ and $10^{-5}$ mbar. Prior to every titration experiment, the content of the sample-holder is pumped during a few minutes, in order to obtain the same pressure as in the reactor. Water and light volatile compounds adsorbed onto particles may be removed during this step. The principle of a titration experiment consists of exposing particles deposited on a suitable filter to the probe gas in the reactor. If a heterogeneous reaction occurs between the probe gas and the surface functional groups, a part of the gas will be taken up by the sample, and the mass spectrometer (MS) signal will quickly decrease, as shown in Figure 2. Once all the functional groups on the surface of the sample have reacted with the gas, the MS signal will come back to its initial value. The number of gas-phase probe molecules taken up by the sample is then calculated by integrating the MS signal (see hatched curve in Figure 2), that has previously been calibrated using measured flow rates of probe gases. Finally, the number of gas-phase probe molecules taken up by the sample is divided either by the particle mass (molecule/mg, see paragraph 2.5) or by the particle surface area (molecule $/ \mathrm{cm}^{2}$, see paragraph 2.6).

\subsection{Probe gases}

Prior to the field campaign, the reactivity of several probe gases was tested using laboratorygenerated aerosols. In preliminary, Demirdjian and Rossi (2005) tested the reactivity of four

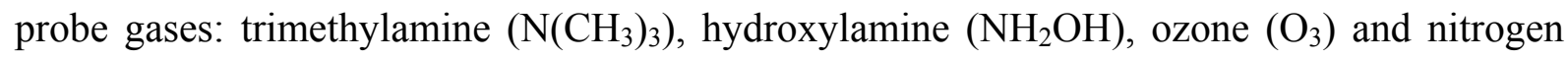
dioxide $\left(\mathrm{NO}_{2}\right)$. Within the framework of the present study, we have evaluated several 
additional probe gases, and decided on $\mathrm{N}\left(\mathrm{CH}_{3}\right)_{3}, \mathrm{NH}_{2} \mathrm{OH}$, trifluoroacetic acid $\left(\mathrm{CF}_{3} \mathrm{COOH}\right)$, hydrochloric acid $(\mathrm{HCl})$ and $\mathrm{O}_{3}$.

Table 2 shows reactions which were generally expected to occur between these five probes and the particle surface at the conditions of the Knudsen flow reactor. Indeed, heterogeneous reactions were studied at ambient temperature, the residence time of the gas-phase probe molecules in the reactor was comprised between $20 \mathrm{~s}$ and $1 \mathrm{~min}$, and their concentration in the reactor was low (in the range $1 \cdot 10^{13}-5 \cdot 10^{13}$ molecule $/ \mathrm{cm}^{3}$ ). Thus, a reaction may be observed using this technique only if it occurs at ambient temperature, and if the kinetics is fast enough to enable a reaction during the residence time of the probe gas in the reactor. This has led to the choice of allowed reactions displayed on the left of Table 2, whereas the reactions on the right were rejected based on the above criteria.

The base $\mathrm{N}\left(\mathrm{CH}_{3}\right)_{3}$ (Sigma-Aldrich Chemie; purum, $\geq 99.0 \%$, Fluka 92251) was chosen for the quantification of acidic sites (Reaction 1 of Table 2). $\mathrm{N}\left(\mathrm{CH}_{3}\right)_{3}$ is also known to form stable complexes with transition metal ions (Reaction 2 of Table 2). $\mathrm{N}\left(\mathrm{CH}_{3}\right)_{3}$ may therefore be considered a specific reagent interacting with Lewis acid sites on the particle surface.

$\mathrm{NH}_{2} \mathrm{OH}$ was expected to specifically react with carbonyl functions to form oximes (Reaction 3 of Table 2). $\mathrm{NH}_{2} \mathrm{OH}$ is also known to be involved in redox reactions (Davis et al., 1951) and in the complexation of several metal ions (Cheng et al., 1994). It may also react as a base, but its proton affinity $\left(803 \mathrm{~kJ} / \mathrm{mol}\right.$; Jolly, 1991) indicates that $\mathrm{NH}_{2} \mathrm{OH}$ is a much weaker base than $\mathrm{N}\left(\mathrm{CH}_{3}\right)_{3}$ (proton affinity $=942 \mathrm{~kJ} / \mathrm{mol}$; Jolly, 1991). $\mathrm{NH}_{2} \mathrm{OH}$ was prepared by thermal decomposition of tertiary hydroxylammonium phosphate according to the method of Schenk (1963).

Two acids of different strength, $\mathrm{CF}_{3} \mathrm{COOH}$ and $\mathrm{HCl}$, were used to quantify basic sites. $\mathrm{CF}_{3} \mathrm{COOH}$ (Sigma-Aldrich Chemie; purum, Fluka 91700) tends to react with basic sites according to Reaction 5 of Table 2, while $\mathrm{HCl}$ (prepared by a reaction between $\mathrm{H}_{2} \mathrm{SO}_{4}$ and $\mathrm{NaCl}$ ) is expected to react according to Reaction 6 of Table 2. Regarding the acidity, $\mathrm{HCl}$ is a far stronger acid than $\mathrm{CF}_{3} \mathrm{COOH}$ in solution, but this trend is opposite in the gas-phase. Because of the absence of solvent effects in the gas-phase, acid-base properties of organic compounds are indeed different from solution acidities. The gas-phase acidity of a compound $\mathrm{AH}$ is determined by the enthalpy change of deprotonation $\left(\Delta_{\mathrm{f}} \mathrm{H}^{\circ}{ }_{\text {deprot }}\right)$, according to the 
reaction $\mathrm{AH} \rightarrow \mathrm{A}^{-}+\mathrm{H}^{+} . \Delta_{\mathrm{f}} \mathrm{H}_{\text {deprot }}^{\circ}$ of $\mathrm{CF}_{3} \mathrm{COOH}$ is $1351 \mathrm{~kJ} / \mathrm{mol}$ (Cumming and Kebarle, 1978), while that of $\mathrm{HCl}$ is $1395 \mathrm{~kJ} / \mathrm{mol}$ (Trainham et al., 1987). This means that $\mathrm{CF}_{3} \mathrm{COOH}$ needs less enthalpy to undergo deprotonation, and therefore it is a stronger acid in the gasphase than $\mathrm{HCl}$. We surmise that gas-phase acidities/basicities are more applicable than solution values in the present context, because species adsorbed on a surface do not undergo extensive solvation after charge separation compared to aqueous solution.

Finally, $\mathrm{O}_{3}$ is a strongly oxidizing probe, and was chosen to quantify oxidizable sites. The main expected reaction is the ozonolysis of carbon-carbon double bonds (Reaction 9 of Table 2), whereas it decomposes on metal oxide surfaces (Dhandapani and Oyama, 1997). Oxidation of alcohols and aldehydes into carboxylic acids is too slow to be observed using this technique. $\mathrm{O}_{3}$ was prepared daily by corona discharge in pure oxygen by means of an ozone generator (Fischer Technology, model 502), and was condensed in a vessel filled with silica gel and maintained in a cold methanol bath $\left(-80^{\circ} \mathrm{C}\right)$.

\subsection{Laboratory-generated aerosols}

In preliminary work, Demirdjian and Rossi (2005) tested the reactivity of probe gases towards several laboratory-generated aerosols. Their titration experiments were carried out on two Secondary Organic Aerosols (SOA; limonene and toluene) and on one soot sample (toluene). In anticipation of the sampling campaign, we chose to carry out titration experiments on four different types of aerosol surrogates for particulate matter expected in bus depots. We used limonene $\mathrm{SOA}$ as a surrogate of organic aerosols, $\mathrm{Pb}\left(\mathrm{NO}_{3}\right)_{2}$ and $\mathrm{Cd}\left(\mathrm{NO}_{3}\right)_{2}$ as surrogates for soluble metals ions, and a sample of certified Diesel particulate matter (SRM 2975).

Limonene SOA was obtained by oxidation of limonene 145 (Sigma-Aldrich Chemie; purum, Fluka 89188) in the presence of ozone. A flow of limonene vapor in air ( $250 \mathrm{ml} / \mathrm{min})$, ozone (3 $\mathrm{ml} / \mathrm{min})$, dry air $(30 \mathrm{ml} / \mathrm{min})$ and wet air $(150 \mathrm{ml} / \mathrm{min})$ was admitted into a reactor (volume $=480 \mathrm{~cm}^{3}$ ), and the outlet of the reactor was linked to a denuder coated with potassium iodide in order to destroy excess ozone. Under these conditions, the relative humidity in the reactor was $37 \%$. Limonene SOA was finally collected on a Teflon membrane filter (Millipore; Fluoropore membrane filter, $0.22 \mu \mathrm{m}, \varnothing 47 \mathrm{~mm}$, FGLP04700) located immediately after the potassium iodide denuder. The yield of limonene SOA $\mathrm{Y}_{\mathrm{SOA}}$ was calculated using Equation 1: 


$$
\mathrm{Y}_{\mathrm{SOA}}=\frac{M_{\mathrm{SOA}}}{F \cdot M W_{\mathrm{lim}} \cdot \Delta t}
$$

where $\mathrm{M}_{\mathrm{SOA}}[\mathrm{g}]$ is the gravimetrically determined mass of limonene SOA collected on the Teflon filter, $\mathrm{F}$ [mole/h] the flow rate of limonene into the reactor, $\mathrm{MW}_{\lim }[\mathrm{g} / \mathrm{mole}]$ the molecular weight of limonene, and $\Delta \mathrm{t}[\mathrm{h}]$ the duration of SOA generation.

Lead (II) nitrate $\left(\mathrm{Pb}\left(\mathrm{NO}_{3}\right)_{2}\right.$; Merck; GR for analysis ACS, 107398) and cadmium (II) nitrate $\left(\mathrm{Cd}\left(\mathrm{NO}_{3}\right)_{2}\right.$; Acros Organics; cadmium nitrate tetrahydrate 99+\%, 212342500) particles were obtained by atomization of an aqueous salt solution $(2 \mathrm{~g} / \mathrm{l})$. We used a constant output atomizer (TSI Inc., model 3076), and the aerosols were dried after flowing in a stream of filtered air across two diffusion dryers (TSI Inc., model 3062) filled with silica gel and connected in series. Under these conditions, the relative humidity after passage across the both diffusion dryers was 5\%. Particles were also collected on a Teflon membrane filter.

A commercially available certified Diesel soot sample (SRM 2975, NIST) was also investigated using the Knudsen flow reactor. A few milligrams of powder were weighed on a teflonized Petri dish and installed in the sample-holder of the Knudsen flow reactor.

\subsection{Field campaign}

A field campaign was conducted in several bus depots in Switzerland between March 2006 and February 2007. The aim of this field campaign was to collect particles on filters, and to quantify several surface functional groups of these samples using the Knudsen flow reactor. For each bus depot, sampling took place during two consecutive days. We installed our equipment in mechanical maintenance yards as close as possible to the workplace. Particles collected originated either from tens of Diesel buses or from activities of workers during repair and maintenance of the buses (solvents, Diesel fuel, engine trial runs, dust, cigarette smoke, etc.). A description of the sampling sites is given in Table 3.

Filters used during the sampling had to allow passage of considerable air flows across the high-volume samplers $(580 \mathrm{l} / \mathrm{min})$, and at the same time had to be chemically inert towards the probe gases used in the Knudsen flow reactor. We evaluated several filter types and passivation methods, and finally decided to use quartz microfiber filters, after chemical passivation with a reactive silane reagent in order to decrease their reactivity towards the 
probe gases. We first cut filters of $150 \mathrm{~mm}$ diameter and several filters of $47 \mathrm{~mm}$ diameter for the blanks from quartz microfiber sheets (Whatman; QM-A, 20x23 cm sheets, 1851865). These filters were cleaned in a solution of chromic acid for $4 \mathrm{~h}$, and were washed seven times with tap water and three times with bidistilled water. The filters were then dried at $150^{\circ} \mathrm{C}$ during $2 \mathrm{~h}$, and were left overnight in a solution of $20 \%$ dichlorodimethylsilane (Acros Organics; 99+\%, 11331-0010) in toluene inside a desiccator, in order to avoid toluene evaporation and reaction of the silane with air moisture. The following day, the filters were washed three times with toluene and once with distilled methanol, and were finally dried at $120^{\circ} \mathrm{C}$ during $1 \mathrm{~h}$.

After preparation of the filters, ambient particles were sampled in each bus depot with two high-volume samplers (Digitel, model DH 77) located side by side. Particles were collected on silanized quartz microfiber filters of $150 \mathrm{~mm}$ diameter at an air flow of $580 \mathrm{l} / \mathrm{min}$ during approximately $8 \mathrm{~h}$ for each day of sampling. An impactor was installed above the filter-holder in order to remove particles larger than $4 \mu \mathrm{m}$. Immediately after sampling, the filters of 150 $\mathrm{mm}$ diameter were cut into five smaller filters of $47 \mathrm{~mm}$ diameter, and put into a desiccator filled with argon. This experimental setup allowed for a total of 10 small filters of $47 \mathrm{~mm}$ diameter to be used for surface chemical titration using the Knudsen flow reactor.

\subsection{Particle mass}

The particle mass deposited on the filters was measured gravimetrically using an analytical balance (Mettler Toledo, model AT 201). For the laboratory-generated aerosols, the Teflon filters were weighed before and after aerosol generation. For the field campaign, five small filters of $47 \mathrm{~mm}$ diameter coming from one high-volume sampler and five blanks, which had been silanized in the same batch, were let to stabilize overnight at constant relative humidity and temperature. All the filters were subsequently weighed, and the particle mass deposited on the filters was calculated by subtracting the average mass of the blanks from the loaded filters.

\subsection{Particle size distribution}

A Scanning Mobility Particle Sizer (SMPS; TSI Inc., model 3934) was used to monitor the size distribution and to calculate the surface area of the laboratory-generated aerosols. The aerosol sampling flow was set at $0.3 \mathrm{1} / \mathrm{min}$, and the sheath flow at $31 / \mathrm{min}$. An impactor of $0.0508 \mathrm{~cm}$ diameter was installed at the inlet of the SMPS in order to remove particles larger 
than $1 \mu \mathrm{m}$. The particle size distribution was measured in the range $15-750 \mathrm{~nm}$, with a scanning time of 150 seconds. The SMPS was regularly calibrated by atomization of solutions containing latex polymers of known size (80 and $300 \mathrm{~nm}$; Duke Scientific Corporation). The particle size distribution was used to calculate the particle surface area S. For that purpose, the software considered each particle as a sphere of radius $r$, according to $S=4 \pi r^{2}$. The geometric standard deviation $\left(\sigma_{\mathrm{g}}\right)$ was calculated in order to provide an indication of the particle dispersion. $\sigma_{\mathrm{g}}$ was calculated according to Equation 2:

$$
\ln \sigma_{\mathrm{g}}=\sqrt{\frac{\sum_{i=m}^{n} N_{i}\left(\ln d_{i}-\ln d_{g}\right)^{2}}{N-1}}
$$

\section{Equation 2}

where $\mathrm{m}$ is the first channel, $\mathrm{n}$ the last channel, $\mathrm{N}_{\mathrm{i}}\left[\right.$ particle $/ \mathrm{cm}^{3}$ ] the concentration within the channel $\mathrm{i}, \mathrm{d}_{\mathrm{i}}[\mathrm{nm}]$ the midpoint diameter for size channel $\mathrm{i}, \mathrm{d}_{\mathrm{g}}[\mathrm{nm}]$ the geometric mean diameter, and $\mathrm{N}\left[\right.$ particle $\left./ \mathrm{cm}^{3}\right]$ the total concentration.

The normalization of the titration results of the certified Diesel SRM 2975 particles was performed using the values of the BET surface area specified by the manufacturer rather than using the measured particle size distributions based on mobility diameters. We concede that the specific surface area calculated using the SMPS and that measured by the BET technique may be significantly different. Indeed, the mobility measurement considers each particle to be spherical, while the $\mathrm{N}_{2}$ adsorption used in the BET technique takes into account the shape and the porosity of the particles. This may lead to a significantly higher value of the specific surface area determined by the BET technique, which may be considered as an upper limit to the surface area determined by the effective mobility diameter. Therefore, we may not directly compare the surface area of SRM 2975 with the aerosol samples measured using the SMPS.

For the field campaign, further equipment had to be used for the particle surface area, because the upper size limit of the SMPS was fixed at $750 \mathrm{~nm}$, while the high-volume samplers were set to collect particles up to $4 \mu \mathrm{m}\left(\mathrm{PM}_{4}\right)$. In order to take into account the particle fraction between $750 \mathrm{~nm}$ and $4 \mu \mathrm{m}$, we used in addition an Andersen type cascade impactor (Andersen Inc.; model 2000, nine-stages) at a sampling flow of $28 \mathrm{l} / \mathrm{min}$, and collected particles on glass 
microfiber filters installed on each of the nine stages of the apparatus. At each sampling site, the Andersen impactor was installed next to the high-volume samplers, and the sampling was performed simultaneously. The particle mass deposited on each filter stage was measured gravimetrically, and the four stages corresponding to sizes between $750 \mathrm{~nm}$ and $4.7 \mu \mathrm{m}$ were used to calculate the missing particle surface area when using the SMPS. The particle mass was converted into surface area using the surface/volume ratio and an estimated density of 1.8 $\mathrm{g} / \mathrm{cm}^{3}$. Finally, data collected with the SMPS (for particles smaller than $750 \mathrm{~nm}$ ) and the Andersen impactor (for particles in the range $750 \mathrm{~nm}-4 \mu \mathrm{m}$ ) at each sampling site were combined in order to determine the surface area of all $\mathrm{PM}_{4}$ samples collected using the highvolume samplers. Calculations indicated that approximately $10-30 \%$ of the total $\mathrm{PM}_{4}$ surface area was due to particles in the size range $750 \mathrm{~nm}-4 \mu \mathrm{m}$. Therefore the use of the Andersen impactor was necessary to correct data obtained from the SMPS by adding the missing surface area. However, we are aware of the approximation due to the transfer of this correction factor obtained from an aerodynamic (Andersen impactor) to a mobility measurement (SMPS). We deem this difference to be less than $10 \%$.

\subsection{Kinetics of heterogeneous titration reactions}

Besides the quantification of surface functional groups on aerosol particles, we also measured the uptake kinetics of reactions between aerosols and probe gases, in order to obtain further information about the reactivity of the collected particulate matter. The kinetic parameter studied within the framework of this project was the initial uptake coefficient $\gamma_{0}$, which corresponds to the probability that a collision between a probe gas and a sample leads to a chemical reaction just after opening the sample compartment. The $\gamma_{0}$ value can range from 0 , which corresponds to no reaction, to 1 , when each collision between the probe gas and the sample leads to an uptake of the probe gas. For the case of $\gamma_{0}$ equal to 1 , the reaction will be saturated very quickly. The uptake coefficient $\gamma_{0}$ was calculated using Equation 3:

$$
\gamma_{0}=\frac{\mathrm{k}_{\mathrm{uni}}}{\omega}
$$

Equation 3

where $\mathrm{k}_{\text {uni }}\left[\mathrm{s}^{-1}\right]$ is the first order rate constant for the uptake reaction, and $\omega\left[\mathrm{s}^{-1}\right]$ the collision frequency of a molecule with the geometric surface area of a sample. $k_{\text {uni }}$ was calculated using Equation 4: 


$$
\mathrm{k}_{\mathrm{uni}}=\left(\frac{\mathrm{S}_{0}}{\mathrm{~S}_{\mathrm{R}}}-1\right) \cdot \mathrm{k}_{\mathrm{esc}}
$$

\section{Equation 4}

where $\mathrm{S}_{0}[\mathrm{~V}]$ is the MS signal at steady state, and $\mathrm{S}_{\mathrm{R}}[\mathrm{V}]$ the MS signal immediately after the beginning of the reaction, as shown in Figure 2. $\mathrm{k}_{\mathrm{esc}}\left[\mathrm{s}^{-1}\right]$ is the escape rate constant of the probe gas from the reactor, and is measured experimentally. Finally, in order to calculate $\gamma_{0}$ in Equation 3, $\omega$ was determined as follows:

$$
\omega=\left(\frac{\bar{c}}{4 \cdot V}\right) \cdot A_{s}
$$

Equation 5

where $\bar{c}[\mathrm{~cm} / \mathrm{s}]$ is the mean velocity of the gas-phase probe molecule, $\mathrm{V}\left[\mathrm{cm}^{3}\right]$ the volume of the reactor, and $\mathrm{A}_{\mathrm{s}}\left[\mathrm{cm}^{2}\right]$ the geometric surface area of the sample. Further information on kinetic parameters may be found in Caloz et al. (1997).

\section{Results and Discussion}

\subsection{Laboratory-generated aerosols}

Particle size distributions measured using the SMPS indicated that laboratory-generated aerosols had systematically a single mode $(>230 \mathrm{~nm}$ for limonene SOA, approximately $55 \mathrm{~nm}$ for inorganic particles), and followed a perfect log-normal distribution. The geometric standard deviations $\left(\sigma_{\mathrm{g}}\right)$ were 1.58 for limonene SOA, and 1.75 for inorganic particles. We note that the used equipment did not allow us to check whether or not particles larger than $750 \mathrm{~nm}$ were generated. We make the assumption that the contribution of particles larger than $750 \mathrm{~nm}$ to the total surface area will be small, which is in agreement with the measured particle size distribution from the SMPS.

The yield of limonene SOA, calculated using Equation 1, indicated that only $2 \%$ of the limonene used for SOA generation was converted into SOA and collected on the Teflon filter. In contrast, the yield was much higher (55\%) in the previous study of Demirdjian and Rossi 2005. Actually, the present limonene SOA sample and that of Demirdjian and Rossi (2005) were not generated under the same conditions. The main difference between both conditions was the residence time of limonene in the reactor, which was approximately $2 \mathrm{~min}$ for the 
conditions of Demirdjian and Rossi (2005), and 1 min under the present conditions. This difference explains the low yield obtained under the present conditions. Moreover, previous publications highlighted reduced yields due to deposition and loss of particles to the walls of the reactors (Shilling et al., 2008).

The uptake of probe gases on laboratory-generated aerosols and Diesel soot SRM 2975 is shown in Figure 3. The number of gas-phase probe molecules taken up by the samples was divided either by the particle mass (Figure 3, left column) or by the particle surface area (Figure 3, right column) as discussed above. In order to facilitate comparison between these values, we also calculated the approximate number of molecules per $\mathrm{cm}^{2}$ forming a complete molecular monolayer on the particle surface using the density of each probe (Table 4).

Figures 3(a), 3(b) and Table 4 indicate that the surface of SRM 2975 is characterized by an important density of acidic sites interacting with $\mathrm{N}\left(\mathrm{CH}_{3}\right)_{3}$, corresponding to approximately $15 \%$ of a monolayer, while that of limonene SOA and of inorganic aerosols corresponds to less than $5 \%$ of a monolayer. This confirms the high degree of oxidation of the particle surface for soot collected from a heavy duty industrial forklift engine. The fact that inorganic aerosols interact with this probe suggests that metals could form coordination complex with $\mathrm{N}\left(\mathrm{CH}_{3}\right)_{3}$.

$\mathrm{NH}_{2} \mathrm{OH}$ reacted to a large extend with all the samples. This result indicates the presence of an important amount of carbonyl functions on the surface of limonene SOA and SRM 2975. However, reactions with $\mathrm{Pb}\left(\mathrm{NO}_{3}\right)_{2}$ and $\mathrm{Cd}\left(\mathrm{NO}_{3}\right)_{2}$ are more surprising. These reactions might be due to complexation of metal ions by $\mathrm{NH}_{2} \mathrm{OH}$. It is also possible that $\mathrm{NH}_{2} \mathrm{OH}$ decomposes on metal surfaces, by analogy to the oxidation of $\mathrm{NH}_{2} \mathrm{OH}$ to $\mathrm{NO}$ on a $\mathrm{Fe}_{2} \mathrm{O}_{3}-\mathrm{TiO}_{2}$ catalyst (Larrubia et al., 2001). The number of $\mathrm{NH}_{2} \mathrm{OH}$ taken up corresponds to several molecular monolayers (see Table 4). This suggests that during the time scale of a titration experiment (approximately 10 minutes), subsurface reactions with $\mathrm{NH}_{2} \mathrm{OH}$, consisting of diffusion and subsequent reaction of carbonyl compounds from within the bulk of the aerosol with $\mathrm{NH}_{2} \mathrm{OH}$, may take place, akin to the reaction of $\mathrm{NH}_{2} \mathrm{OH}$ with limonene SOA (Demirdjian and Rossi, 2005).

Of both acidic probes which were used to quantify basic sites on the particle surface, the uptake of $\mathrm{HCl}$ was higher than for $\mathrm{CF}_{3} \mathrm{COOH}$ on $\mathrm{Pb}\left(\mathrm{NO}_{3}\right)_{2}, \mathrm{Cd}\left(\mathrm{NO}_{3}\right)_{2}$ and $\mathrm{SRM} 2975$ aerosol. 
$\mathrm{CF}_{3} \mathrm{COOH}$ is a stronger acid in the gas-phase, and therefore was expected to react with more basic sites, even with the weakest ones. Thus the extensive reaction of $\mathrm{HCl}$ in comparison to $\mathrm{CF}_{3} \mathrm{COOH}$ can not be explained exclusively on the basis of gas-phase acidities. Enthalpy changes of these reactions have been calculated using thermodynamic data (Wagman et al., 1982), and may provide an explanation for these changes. However, thermodynamic data for trifluoroacetic acid and trifluoroacetates are not available in the literature. Therefore we used the analogous values given for acetic acid and acetates. For instance in the case of $\mathrm{Pb}\left(\mathrm{NO}_{3}\right)_{2}$, results indicate that the reaction with $\mathrm{HCl}$ is less endothermic (Reaction $\mathrm{B}: \Delta \mathrm{H}_{\mathrm{f}}^{\circ}=+12.1$ $\mathrm{kJ} / \mathrm{mol}$ ) than that with $\mathrm{CH}_{3} \mathrm{COOH}$ (Reaction $\mathrm{A}: \Delta \mathrm{H}_{\mathrm{f}}^{\circ}=+45.3 \mathrm{~kJ} / \mathrm{mol}$ ), and therefore should be favored during the titration experiment in the Knudsen flow reactor.

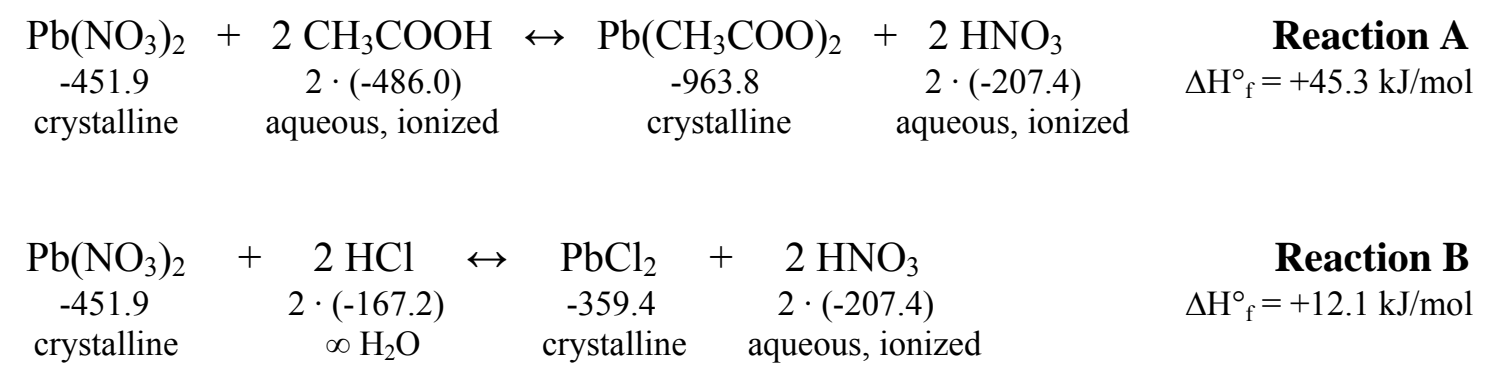

Ozone reacted only with particles containing organics, such as limonene SOA $(7.7 \%$ of a complete molecular monolayer, Table 4) and SRM 2975 Diesel particle (1.2\% of a complete molecular monolayer, Table 4). However, in our earlier study (Demirdjian and Rossi, 2005; DR), limonene SOA did not react with $\mathrm{O}_{3}$. The results for limonene SOA presented here suggest an incomplete oxidation of the precursor. This could be related to the shorter residence time of limonene in the reactor pointed out above, or to a lower $\mathrm{O}_{3}$ concentration in the present experiments compared to DR, or both. Thus, limonene SOA obtained under the present conditions was less oxidized than that generated by DR. This may explain the difference in reactivity towards $\mathrm{O}_{3}$ observed between both samples. Indeed, if limonene SOA is more oxidized, more acidic sites and carbonyl functions are expected. This is confirmed for the uptakes of $\mathrm{N}\left(\mathrm{CH}_{3}\right)_{3}$ and $\mathrm{NH}_{2} \mathrm{OH}$. Actually, the uptake of $\mathrm{N}\left(\mathrm{CH}_{3}\right)_{3}$ corresponds to $5.0 \%$ of a monolayer for the DR sample, as compared to $3.6 \%$ for the present sample, confirming the presence of a larger number of acidic sites on the surface of the DR limonene SOA. For the surface density of carbonyl functions, the uptake of $\mathrm{NH}_{2} \mathrm{OH}$ corresponded to more than 31 monolayers for the DR sample, and five monolayers for the present sample, thus confirming a higher content of carbonyl functions for the DR sample. The significant uptake of ozone on 
Diesel SRM 2975 is indicative of the presence of unsaturated carbon-carbon double bonds, which could be either olefinic or aromatic in nature. Such Diesel particles apparently significantly differ from toluene soot (Demirdjian and Rossi, 2005). Based on $\mathrm{N}\left(\mathrm{CH}_{3}\right)_{3}$, $\mathrm{NH}_{2} \mathrm{OH}$ and $\mathrm{O}_{3}$ uptake, SRM 2975 presents a significantly higher degree of oxidation compared to toluene soot.

Figure 3 and Table 4 indicate that the reactivities of $\mathrm{Pb}\left(\mathrm{NO}_{3}\right)_{2}$ and $\mathrm{Cd}\left(\mathrm{NO}_{3}\right)_{2}$ towards all probe gases, except for the case of the non-interacting ozone, are significantly different from each other, although the oxidation state of the metal ion and the conditions used to generate these particles were identical. For the reactivity towards $\mathrm{HCl}$, chemical thermodynamic properties of Reactions $\mathrm{B}$ and $\mathrm{C}$ indicate that the reaction of $\mathrm{HCl}$ with $\mathrm{Cd}\left(\mathrm{NO}_{3}\right)_{2}$ is exothermic (Reaction $\mathrm{C}: \Delta \mathrm{H}_{\mathrm{f}}^{\circ}=-15.6 \mathrm{~kJ} / \mathrm{mol}$ ), whereas that with $\mathrm{Pb}\left(\mathrm{NO}_{3}\right)_{2}$ is endothermic (Reaction $\mathrm{B}: \Delta \mathrm{H}_{\mathrm{f}}^{\circ}=+12.1 \mathrm{~kJ} / \mathrm{mol}$ ). Reaction $\mathrm{C}$ should therefore be favored over Reaction $\mathrm{B}$, which is in agreement with the uptake of $\mathrm{HCl}$ being higher by a factor of five for $\mathrm{Cd}\left(\mathrm{NO}_{3}\right)_{2}$ $\left(9.0 \cdot 10^{14}\right.$ molecule $\left./ \mathrm{cm}^{2}\right)$ compared to $\mathrm{Pb}\left(\mathrm{NO}_{3}\right)_{2}\left(2.0 \cdot 10^{14}\right.$ molecule $\left./ \mathrm{cm}^{2}\right)$.

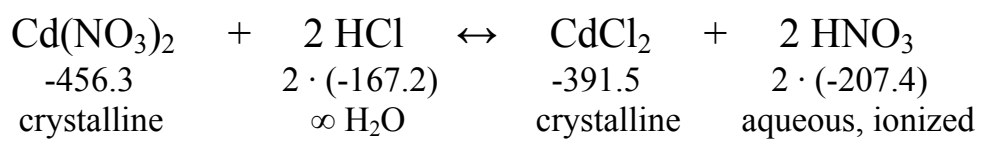

\author{
Reaction C \\ $\Delta \mathrm{H}_{\mathrm{f}}^{\circ}=-15.6 \mathrm{~kJ} / \mathrm{mol}$
}

On the other hand, we cannot exclude the formation of hydroxides during the generation of inorganic aerosols, according to Reactions D and E. In this case, nitric acid $\left(\mathrm{HNO}_{3}\right)$ would evaporate, while $\mathrm{Pb}(\mathrm{OH})_{2}$ (Reaction $\mathrm{D}$ ) and $\mathrm{Cd}(\mathrm{OH})_{2}$ (Reaction $\mathrm{E}$ ) would be collected on the Teflon filters and react with $\mathrm{HCl}$ or $\mathrm{CF}_{3} \mathrm{COOH}$ in the Knudsen flow reactor. Thus, it is possible that during the generation of inorganic aerosols, a mixture of nitrates and hydroxides is produced and collected on the Teflon filters.

$$
\begin{aligned}
& \mathrm{Pb}\left(\mathrm{NO}_{3}\right)_{2}+2 \mathrm{H}_{2} \mathrm{O} \leftrightarrow \mathrm{Pb}(\mathrm{OH})_{2}+2 \mathrm{HNO}_{3} \\
& \mathrm{Cd}\left(\mathrm{NO}_{3}\right)_{2}+2 \mathrm{H}_{2} \mathrm{O} \leftrightarrow \mathrm{Cd}(\mathrm{OH})_{2}+2 \mathrm{HNO}_{3}
\end{aligned}
$$

Reaction D

Reaction E

Boehm and Voll (1970) reported that basic oxides on the surface of amorphous carbon have more affinity towards $\mathrm{CH}_{3} \mathrm{COOH}$ than $\mathrm{HCl}$. Figures 3(e), 3(f), 3(g), 3(h) and Table 4 indicate a selectivity of limonene $\mathrm{SOA}$ for $\mathrm{CF}_{3} \mathrm{COOH}$ over $\mathrm{HCl}$ uptake. Therefore, we assume that the 
generation of limonene SOA leads to formation of basic oxides on the SOA surface. This result has been observed on other combustion aerosols such as amorphous carbon as well (Setyan et al., 2008). Similar considerations suggest that SRM 2975 Diesel particles lack such basic oxide functions on their surface.

The uptake coefficients $\gamma_{0}$ of the titration reactions between probe gases and laboratorygenerated aerosols are shown in Table 5. Reactions with $\gamma_{0}$ smaller than $10^{-4}$ may be considered as slow, while those higher than $10^{-3}$ as fast. Table 5 reveals large values of $\gamma_{0}$ for the rate of $\mathrm{N}\left(\mathrm{CH}_{3}\right)_{3}$ uptake on SRM 2975 as well as for $\mathrm{NH}_{2} \mathrm{OH}$ uptake on SRM 2975 and limonene SOA. A look at the corresponding uptake values displayed in Table 4 indicates that there is no apparent relationship between the kinetics (Table 5) and uptakes (Table 4). This suggests that the kinetic behavior is different for different kinds of particles using the same probe and/or reflects a different reaction mechanism for probe uptake for the same class of particles.

\subsection{Field campaign}

Prior to the field campaign, we had to ascertain that the silanized quartz fiber filters were chemically sufficiently inert towards the used probe gases. Figure 4 displays the reactivity of silanized and non-silanized quartz fiber filters towards all used probe gases. Results indicate that silanization of filters decreased their reactivity up to 50 times for $\mathrm{HCl}$, which was the most reactive probe. We therefore considered silanized quartz fiber filters as suitable filters for the field campaign.

Size distributions of ambient particles measured using the SMPS showed a very large variability during the working period in the bus depots, depending on the activities of workers. One mode in the size range $50-70 \mathrm{~nm}$ was systematically present on all the scans, and a second mode in the size range 20-30 nm was sometimes observed immediately after the passage of buses next to the SMPS, due to the emission of small particles.

Figure 3 shows the uptake of probe gases on aerosols collected in the field. These results were obtained by first subtracting each sample by a blank which had been silanized in the same batch. Then, the number of gas-phase probe molecules taken up by the whole sample was divided by the particle mass (molecule/mg; Figure 3, left column). In order to determine the 
density of functional groups on the particle surface (molecule $/ \mathrm{cm}^{2}$; Figure 3, right column), the number of gas-phase probe molecules taken up by the whole sample was divided by the particle surface area. As for laboratory-generated aerosols, we also expressed these results as the percentage of a complete molecular monolayer on the particle surface using the density of each probe, in order to facilitate comparison between these values (Table 4).

In Figure 3, results expressed as the number of probe molecules taken up per particle mass (left column) do not show the same detailed trends as those expressed according to the particle surface area (right column). In order to obtain insight on a molecular level into the reactivity of the particle surface, we base the following discussion on results expressed as the number of probe molecules taken up per unit of particle surface area $\left(\right.$ molecule $\left./ \mathrm{cm}^{2}\right)$. This choice is motivated by previous studies, which pointed out the importance of surface reactivity to the toxicity of nanoparticles (Warheit et al., 2007) and to the ability of particulate matter to adsorb a wide variety of compounds (proteins, surfactant components) in the lung (Kendall et al., 2004b).

In Figure 3 (right column), the surface reactivity of the collected aerosols showed a large variability according to the workplace and the season. Indeed, the difference of probe gas uptake between the most reactive and the less reactive sample could reach a factor of 100 . These differences may be due to various activities of the workers in the bus depots, and also to the background of outdoor air. Moreover, almost all the samples reacted with the five probe gases, which indicate that the particle surface is multi-functional, with the simultaneous presence of antagonistic functional groups on the same particle, such as Lewis acids and bases. Apparently, these mutually reactive sites are able to coexist on the particle surface without the occurrence of the expected neutralization reaction.

There were several similarities between laboratory-generated aerosols and aerosols collected in the field. First, the uptake of $\mathrm{NH}_{2} \mathrm{OH}$ on all samples was very large. As with the laboratorygenerated aerosols, these results indicate the presence of an important amount of carbonyl functions on the particle surface. This result is in agreement with previous studies, which also suggested that carbonyl functions are significant constituents of ambient particulate matter (Reff et al., 2005). Moreover, Figures 3(f) and 3(h) indicate that $\mathrm{HCl}$ reacted to a larger extent compared to $\mathrm{CF}_{3} \mathrm{COOH}$ with all the samples. As discussed for laboratory-generated aerosols, particulate matter sampled in all the bus depots seems to contain a low amount of basic oxides 
that are related to $\alpha / \gamma$ pyrone structures (Setyan et al., 2008). On the other hand, among all the investigated samples (laboratory-generated aerosols as well as aerosols collected in the field), limonene $\mathrm{SOA}$ is the only one to have a higher selectivity towards $\mathrm{CF}_{3} \mathrm{COOH}(5.3 \%$ of a monolayer, Table 4 ) than towards $\mathrm{HCl}$ (less than $0.5 \%$ of a monolayer, corresponding to the limit of detection for $\mathrm{HCl}$; Table 4). This result suggests that limonene SOA is perhaps not a good surrogate for organic aerosols in bus depots.

Figures 3(b) and 3(j) show that aerosols collected in the field present anticorrelated reactivities towards $\mathrm{N}\left(\mathrm{CH}_{3}\right)_{3}$ and $\mathrm{O}_{3}$. Indeed, particles sampled in the bus depot 2 in winter reacted strongly with $\mathrm{O}_{3}$ (Figure 3(j)), but not with $\mathrm{N}\left(\mathrm{CH}_{3}\right)_{3}$ (Figure 3(b)). On the other hand, particles sampled in summer reacted with $\mathrm{N}\left(\mathrm{CH}_{3}\right)_{3}$ (Figure 3(b)), while reactions with $\mathrm{O}_{3}$ were near the limit of detection ((Figure 3(j)). This suggests that during summer, particles may have undergone photo-oxidation, which generated carboxylic acids and increased the oxidation state of the organic aerosol. The presence of carboxylic acids on particles in summer explains the reactivity of these samples towards $\mathrm{N}\left(\mathrm{CH}_{3}\right)_{3}$, while the very weak reactions with $\mathrm{O}_{3}$ may be attributed to the fact that such a high oxidation status prevents further oxidation by the $\mathrm{O}_{3}$ probe. In contrast, photo-oxidation does not occur in winter, and therefore compounds adsorbed on particles sampled in winter were in a reduced state. These samples did not react with $\mathrm{N}\left(\mathrm{CH}_{3}\right)_{3}$ because of the absence of carboxylic acids, whereas they underwent oxidation by $\mathrm{O}_{3}$. This observation points to the influence of the background of outdoor air on the results, because photo-oxidation usually does not occur in an indoor environment. These observations are in agreement with results obtained by previous studies (Kawamura and Ikushima, 1993), which also noticed higher levels of acids in particulate matter during summer. Moreover, the presence of a higher content of acidic sites on particles sampled in summer may play a role in the formation of SOA, since Jang et al. (2002) found that acidic surface sites on atmospheric aerosol particles catalyze carbonyl heterogeneous reactions, and consequently lead to a large increase in SOA production.

Compared to laboratory-generated aerosols and certified Diesel soot SRM2975, the uptake of probe gases on aerosols collected in the field was in general of the same order of magnitude. The reactivity of samples containing organics (aerosols collected in the field, limonene SOA and SRM 2975) towards $\mathrm{N}\left(\mathrm{CH}_{3}\right)_{3}, \mathrm{NH}_{2} \mathrm{OH}$ and $\mathrm{O}_{3}$ may be explained by the degree of partial oxidation, while that towards $\mathrm{HCl}$ and $\mathrm{CF}_{3} \mathrm{COOH}$ is mainly explained by the presence of basic sites, including basic oxides. However, due to the very complex mixture of aerosols 
collected in the field, we are unable to express the observed reactivity in terms of fractions of model or laboratory aerosol present in ambient particles.

Concerning the kinetics of the titration reactions, Table 6 displays the uptake coefficient $\gamma_{0}$ of the titration reactions between probe gases and aerosols collected in the field. All aerosol samples reacted fairly slowly with $\mathrm{N}\left(\mathrm{CH}_{3}\right)_{3}$, which points to the presence of organic carboxylic rather than mineral acids. Except for the aerosols collected in bus depot 2 in winter, $\mathrm{NH}_{2} \mathrm{OH}$ reacted roughly at a uniform rate with all aerosol samples with $\gamma_{0}$ being on the order of $10^{-4}$. Moreover, all aerosol samples consistently reacted faster with $\mathrm{HCl}$ than with $\mathrm{CF}_{3} \mathrm{COOH}\left(\gamma_{0}(\mathrm{HCl})>\gamma_{0}\left(\mathrm{CF}_{3} \mathrm{COOH}\right)\right)$. The fastest titration reaction throughout all aerosol samples was invariably that with $\mathrm{O}_{3}$. If there are oxidizable groups present on the aerosol, or if the uptake is significant (see Figure 3), then the reaction becomes very efficient with $\gamma_{0}>$ $10^{-3}$. The ability of aerosols collected in the field to undergo fast redox reactions with $\mathrm{O}_{3}$ and slow acid-base reactions with $\mathrm{N}\left(\mathrm{CH}_{3}\right)_{3}$ is an interesting outcome of this study, regarding the health effects of particulate matter. Indeed, the quantification of the density of surface functional groups by titration with selected probe gases may not be sufficient to explain the reactivity of particulate matter if the kinetics is very slow. For instance, if the particle surface is characterized by a high density of acidic sites, the slow kinetics may prevent excessive damages in biological systems due to acid-base reactions, and therefore may well reduce the adverse health effects of particulate matter.

\section{Conclusion}

In this paper, we report the use of a novel method allowing the quantitative characterization of functional groups on the surface of particulate matter. The Knudsen flow reactor provides an alternative approach to spectroscopic methods, focusing more on the chemical reactivity of the particle surface. We do not claim that this method allows one to study the reactivity of aerosol particles in the aqueous phase. Rather, it provides benchmark data that allows one to map the surface composition of the aerosol interface that represents the first step in the effort of future fundamental understanding of the condensed phase reactivity in biologically relevant environments. The sensitivity of the method allowed detecting less than $1 \%$ of a molecular monolayer of surface functional groups. 
The work undertaken on laboratory-generated aerosols allowed the selection of five different probe gases, namely $\mathrm{N}\left(\mathrm{CH}_{3}\right)_{3}, \mathrm{NH}_{2} \mathrm{OH}, \mathrm{CF}_{3} \mathrm{COOH}, \mathrm{HCl}$ and $\mathrm{O}_{3}$, for the titration of important functional groups, such as acids, bases, carbonyl functions and oxidizable sites.

In the second part of this work, the Knudsen flow reactor was successfully used for the first time to study aerosols collected in the field. Results showed important differences in surface functional groups, depending on sampling sites, season, particle sources, activities of workers and background of outdoor air. The particle surface in bus depots was usually characterized by a high content of carbonyl functions, and showed a high degree of partial oxidation. However, because of the extensive variability of the particle surface in the different bus depots, we are unable to give a description of the surface of typical ambient fine and ultrafine particles. The ability of almost all samples to react with the five probe gases indicates that the particle surface is multi-functional, with the simultaneous presence of antagonistic functional groups which do not undergo internal chemical reactions, such as acid-base neutralization. The measurement of kinetic parameters for aerosols collected in the field indicated that redox reactions of oxidizable sites on the surface of particulate matter were fast, while reactions of acidic sites on particulate matter towards $\mathrm{N}\left(\mathrm{CH}_{3}\right)_{3}$ were rather slow.

Results reported in this paper point out interesting perspectives of this technique in the fields of atmospheric chemistry and health effects of particulate matter. However, additional work has still to be performed in order to find probe gases allowing the quantification of other functional groups. In particular, it would be important to find probe gases reacting specifically with metal ions and oxidizing agents, because these classes of compounds are suspected to play a central role in health effects of particulate matter.

\section{Acknowledgments}

This research project was supported by the Swiss State Secretariat for Education and Research within the framework of the COST Action 633 "Particulate Matter - Properties Related to Health Effects". We thank Ferdinando Storti for his support during the field campaign. 


\section{References}

Bachman, G.B., Strawn, K.G., 1968. Ozone oxidation of primary amines to nitroalkanes. Journal of Organic Chemistry, 33, 313-315.

Beauchemin, A.M., Moran, J., Lebrun, M.-E., Séguin, C., Dimitrijevic, E., Zhang, L., Gorelsky, S.I., 2008. Intermolecular Cope-type hydroamination of alkenes and alkynes. Angewandte Chemie International Edition, 47, 1410-1413.

Bhatia, R., Lopipero, P., Smith, A.H., 1998. Diesel exhaust exposure and lung cancer. Epidemiology, 9, 84-91.

Boehm, H.P., Voll, M., 1970. Basische Oberflächenoxide auf Kohlenstoff - I. Adsorption von Säuren. Carbon, 8, 227-240.

Braun, A., 2005. Carbon speciation in airborne particulate matter with C (1s) NEXAFS spectroscopy. Journal of Environmental Monitoring, 7, 1059-1065.

Brown, D.M., Wilson, M.R., MacNee, W., Stone, V., Donaldson, K., 2001. Size-dependant proinflammatory effects of ultrafine polystyrene particles: A role for surface area and oxidative stress in the enhanced activity of ultrafines. Toxicology and Applied Pharmacology, 175, 191-199.

Caloz, F., Fenter, F. F., Tabor, K. D., Rossi, M. J., 1997. Paper I: Design and construction of a Knudsen-cell reactor for the study of heterogeneous reactions over the temperature range 130-750 K: Performances and limitations. Review of Scientific Instruments, 68, 31723179.

Chen, Y., Shah, N., Braun, A., Huggins, F.E., Huffman, G.P., 2005. Electron microscopy investigation of carbonaceous particulate matter generated by combustion of fossil fuels. Energy \& Fuels, 19, 1644-1651.

Cheng, T.-Y., Ponce, A., Rheingold, A.L., Hillhouse, G.L., 1994. Hydroxylamine, hydrazine, and diazene as unidentate ligands in osmium and ruthenium complexes. Angewandte Chemie International Edition in English, 33, 657-659.

Cohen, Z., Keinan, E., Mazur, Y., Varkony, T.H., 1975. Dry ozonation - A method for stereoselective hydroxylation of saturated compounds on silica gel. Journal of Organic Chemistry, 40, 2141-2142.

Cumming, J.B., Kebarle, P., 1978. Summary of gas phase measurements involving acids AH - Entropy changes in proton transfer reactions involving negative ions - Bond dissociation energies $\mathrm{D}(\mathrm{AH})$ and electron affinities $\mathrm{EA}(\mathrm{A})$. Canadian Journal of Chemistry, 56, 1. 
Cwiertny, D.M., Young, M.A., Grassian, V.H., 2008. Chemistry and photochemistry of mineral dust aerosol. Annual Review of Physical Chemistry, 59, 27-51.

Davis, P., Evans, M.G., Higginson, W.C.E., 1951. Some oxidation-reduction reactions of hydroxylamine. Journal of the Chemical Society, 2563-2567.

Demirdjian, B., Rossi, M.J., 2005. The surface properties of SOA generated from limonene and toluene using specific molecular probes: Exploration of a new experimental technique. Atmospheric Chemistry and Physics Discussion, 5, 607-654.

Dhandapani, B., Oyama, S.T., 1997. Gas phase ozone decomposition catalysts. Applied Catalysis B: Environmental, 11 (2), 129-166.

Erickson, R.E., Andrulis Jr, P.J., Collins, J.C., Lungle, M.L., Mercer, G.D., 1969. Mechanism of ozonation reactions - IV. Carbon-nitrogen double bonds. Journal of Organic Chemistry, 34, 2961-2966.

Fermo, P., Piazzalunga, A., Vecchi, R., Valli, G., Ceriani, M., 2006. A TGA/FT-IR study for measuring OC and EC in aerosol samples. Atmospheric Chemistry and Physics, 6, 255266.

Finlayson-Pitts, B.J., Pitts, J.N., 2000. Chemistry of the upper and lower atmosphere Theory, experiments, and applications. Academic Press, San Diego.

Guilbault, G.G., Billedeau, S.M., 1971. Gas phase reactions of trimethylamine and transition metal salts. Journal of Inorganic \& Nuclear Chemistry, 33, 1411-1415.

Horie, O., Moortgat, G.K., 1998. Gas-phase ozonolysis of alkenes - Recent advances in mechanistic investigations. Accounts of Chemical Research, 31, 387-396.

Hossain, M.Z., Machida, S.-I., Nagao, M., Yamashita, Y., Mukai, K., Yoshinobu, J., 2004. Highly selective surface Lewis acid-base reaction: Trimethylamine on $\operatorname{Si}(100) c(4 \times 2)$. Journal of Physical Chemistry B, 108, 4737-4742.

Jang, M., Czoschke, N.M., Lee, S., Kamens, R.M., 2002. Heterogeneous atmospheric aerosol production by acid-catalyzed particle-phase reactions. Science, 298, 814-817.

Jencks, W. P., 1959. Studies on the mechanism of oxime and semicarbazone formation. Journal of the American Chemical Society, 81, 475-481.

Jolly, W.L., 1991. Modern Inorganic Chemistry, $2^{\text {nd }}$ edition, McGraw Hill, New York.

Karagulian, F., Rossi, M.J., 2005. The heterogeneous chemical kinetics of $\mathrm{NO}_{3}$ on atmospheric mineral dust surrogates. Physical Chemistry Chemical Physics, 7, 3150-3162.

Kawamura, K., Ikushima, K., 1993. Seasonal changes in the distribution of dicarboxylic acids in the urban atmosphere. Environmental Science \& Technology, 27, 2227-2235. 
Kendall, M., Guntern, J., Lockyer, N.P., Jones, F.H., Hutton, B.M., Lippmann, M., Tetley, T.D., 2004a. Urban $\mathrm{PM}_{2.5}$ surface chemistry and interactions with bronchoalveolar lavage fluid. Inhalation Toxicology, 16 (suppl. 1), 115-128.

Kendall, M., Brown, L., Trought, K., 2004b. Molecular adsorption at particle surfaces: A PM toxicity mediation mechanism. Inhalation Toxicology, 16 (suppl. 1), 99-105.

Klein, H., Steinmetz, A., 1975. Umsetzung Adsorbierter Aromaten mit Ozon. Tetrahedron Letters, 48, 4249-4250.

Landini, D., Montanari, F., Rolla, F., 1974. Conversion of primary alcohols to alkyl chlorides using aqueous hydrochloric acid in the presence of phase-transfer catalysts. Synthesis, 3738.

Larrubia, M.A., Ramis, G., Busca, G, 2001. An FT-IR study of the adsorption and oxidation of N-containing compounds over $\mathrm{Fe}_{2} \mathrm{O}_{3}-\mathrm{TiO}_{2}$ SCR catalysts. Applied Catalysis B: Environmental, 30 (1/2), 101-110.

Mauderly, J.L., Chow, J.C., 2008. Health effects of organic aerosols. Inhalation Toxicology, $20,257-288$.

Neuberger, M., Schimek, M.G., Horak Jr, F., Moshammer, H., Kundi, M., Frischer, T., Gomiscek, B., Puxbaum, H., Hauck, H., AUPHEP-Team, 2004. Acute effects of particulate matter on respiratory diseases, symptoms and functions: Epidemiological results of the Austrian Project on Health Effects of Particulate Matter (AUPHEP). Atmospheric Environment, 38, 3971-3981.

Park, S., Nam, H., Chung, N., Park, J.-D., Lim, Y., 2006. The role of iron in reactive oxygen species generation from diesel exhaust particles. Toxicology in Vitro, 20, 851-857.

Pope III, C.A., Burnett, R.T., Thurston, G.D., Thun, M.J., Calle, E.E., Krewski, D., Godleski, J.J., 2004. Cardiovascular mortality and long-term exposure to particulate air pollution: Epidemiological evidence of general pathophysiological pathways of disease. Circulation, $109,71-77$.

Qi, J.H., Feng, L.J., Li, X.G., Zhang, M.P., 2006. An X-Ray Photoelectron Spectroscopy study of elements on the surface of aerosol particles. Journal of Aerosol Science. 37, 218227.

Raley, J.H., Rust, F.F., Vaughan, W.E., 1948. Some free radical reactions of hydrogen chloride. Journal of the American Chemical Society, 70, 2767-2770.

Reff, A., Turpin, B.J., Porcja, R.J., Giovennetti, R., Cui, W., Weisel, C.P., Zhang, J., Kwon, J., Alimokhtari, Morandi, M., Stock, T., Maberti, S., Colome, S., Winer, A., Shendell, D., 
Jones, J., Farrar, C., 2005. Functional group characterization of indoor, outdoor, and personal $\mathrm{PM}_{2.5}$ : results from RIOPA. Indoor Air, 15, 53-61.

Rossi, M.J., 2003. Heterogeneous reactions on salts. Chemical Reviews, 103, 4823-4882.

Schenk, P.W., 1963. Hydroxylammonium salts and Hydroxylamine, in: Brauer, G., Handbook of preparative inorganic chemistry, $2^{\text {nd }}$ edition, Vol. I. Academic Press, New York, pp. 500-503.

Shilling, J.E., Chen, Q., King, S.M., Rosenoern, T., Kroll, J.H., Worsnop, D.R., McKinney, K.A., Martin, S.T., 2008. Particle mass yield in secondary organic aerosol formed by the dark

ozonolysis of $\alpha$-pinene. Atmospheric Chemistry and Physics, 8 (7), 2073-2088.

Setyan, A., Sauvain, J.-J., Rossi, M.J., 2009. Functional groups at the gas-particle interface of amorphous carbon, Diesel, hexane flame soot and $\mathrm{TiO}_{2}$ nanoparticles using gas phase probe molecules for titration. Submitted to Physical Chemistry Chemical Physics.

Stadler, D., Rossi, M.J., 2000. The reactivity of $\mathrm{NO}_{2}$ and $\mathrm{HONO}$ on flame soot at ambient temperature: The influence of combustion conditions. Physical Chemistry Chemical Physics, 2, 5420-5429.

Sze, S.-K., Siddique, N., Sloan, J.J., Escribano, R., 2001. Raman spectroscopic characterization of carbonaceous aerosols. Atmospheric Environment, 35, 561-568.

Trainham, R., Fletcher, G.D., Larson, D.J., 1987. One- and two-photon detachment of the negative chlorine ion. Journal of Physics B: Atomic and Molecular Physics, 20, L777L784.

Ullerstam, M., Johnson, M.S., Vogt, R., Ljungström E., 2003. DRIFTS and Knudsen cell study of the heterogeneous reactivity of $\mathrm{SO}_{2}$ and $\mathrm{NO}_{2}$ on mineral dust. Atmospheric Chemistry and Physics, 3, 2043-2051.

Wagman, D.D., Evans, W.H., Parker, V.B., Schumm, R.H., Halow, I., Bailey, S.M., Churney, K.L., Nuttall, R.L., 1982. The NBS tables of chemical thermodynamic properties Selected values for inorganic and $\mathrm{C}_{1}$ and $\mathrm{C}_{2}$ organic substances in SI units. Journal of Physical and Chemical Reference Data, 11 (suppl. 2), 1-\&.

Warheit, D.B., Webb, T.R., Colvin, V.L., Reed, K.L., Sayes, C.M., 2007. Pulmonary bioassay studies with nanoscale and fine-Quartz particles in rats: Toxicity is not dependent upon particle size but on surface characteristics. Toxicological Sciences, 95 (1), 270-280. 


\section{Figure 1}

Schematic drawing of the Knudsen flow reactor.

\section{Figure 2}

Typical raw data of a titration experiment using the Knudsen flow reactor. Sample: aerosols collected in the bus depot 2 (summer, day 2) on silanized quartz fiber filter. Probe gas: $\mathrm{HCl}$. $\mathrm{m} / \mathrm{z}$ : $36 . \mathrm{S}_{0}$ : MS signal at steady state. $\mathrm{S}_{\mathrm{R}}$ : MS signal immediately after the beginning of the reaction.

\section{Figure 3}

Uptake measurements of $\mathrm{N}\left(\mathrm{CH}_{3}\right)_{3}$ (a and b), $\mathrm{NH}_{2} \mathrm{OH}$ (c and $\left.\mathbf{d}\right), \mathrm{CF}_{3} \mathrm{COOH}$ (e and $\left.\mathbf{f}\right), \mathrm{HCl}$ (g and $\mathbf{h}$ ), and $\mathrm{O}_{3}$ (i and $\mathbf{j}$ ) on aerosols using the Knudsen flow reactor. Error bars: combined uncertainty due to mass, surface area and uptake parameters. N/A: not available. N/D: not detected (lower than the limit of detection). $\mathbf{\Delta}$ : laboratory-generated aerosols. $\mathbf{m}$ : bus depot 1 . $\bullet$ : bus depot 2. $\diamond$ : bus depot 3. $\circ$ and $\diamond$ : night time sampling. The broken horizontal line represents the limit of detection, which takes into account the response of the blank filter to the specific probe gas.

Left column: Number of gas-phase probe molecules taken up per $\mathrm{mg}$ of aerosol [molecule/mg].

Right column: Number of gas-phase probe molecules taken up per $\mathrm{cm}^{2}$ of aerosol [molecule $\left./ \mathrm{cm}^{2}\right]$.

\section{Figure 4}

Uptake measurements of probe gases on silanized and non-silanized quartz fiber filters using the Knudsen flow reactor. Units: number of gas-phase probe molecules taken up per filter of $47 \mathrm{~mm}$ diameter. 
Table 1: Knudsen flow reactor parameters.

\begin{tabular}{|l|l|}
\hline Parameter & Value \\
\hline Volume of the reactor & $\mathrm{V}=1830\left[\mathrm{~cm}^{3}\right]$ \\
\hline Estimated surface area of the reactor & $\mathrm{S}=1300\left[\mathrm{~cm}^{2}\right]$ \\
\hline Geometric surface area of the samples & $\mathrm{A}_{\mathrm{s}}=17.3\left[\mathrm{~cm}^{2}\right]$ \\
\hline Escape orifice diameter & $\varnothing=1[\mathrm{~mm}]$ \\
\hline Chopper frequency & $225[\mathrm{~Hz}]$ \\
\hline Concentration of probe gases in the reactor & $1 \cdot 10^{13}$ to $5 \cdot 10^{13}\left[\mathrm{molecule} / \mathrm{cm}^{3}\right]$ \\
\hline Molecular flow rate of probe gases & $2 \cdot 10^{14}$ to $1 \cdot 10^{15}[\mathrm{molecule} / \mathrm{s}]$ \\
\hline Escape rate constant & $\mathrm{k}_{\mathrm{esc}}=0.01 \cdot \sqrt{T / M W}\left[\mathrm{~s}^{-1}\right]$ \\
\hline
\end{tabular}

$\mathrm{T}=$ temperature $[\mathrm{K}]$.

$\mathrm{MW}=$ molecular weight $[\mathrm{g} / \mathrm{mol}]$. 
Table 2: List of different chemical reactions during the titration experiments in the Knudsen flow reactor.

\begin{tabular}{|c|c|c|}
\hline Probes & $\begin{array}{l}\text { Probable reactions occurring at the } \\
\text { conditions of the Knudsen flow reactor }\end{array}$ & $\begin{array}{l}\text { Reactions not expected to occur at the } \\
\text { conditions of the Knudsen flow reactor }\end{array}$ \\
\hline $\mathrm{N}\left(\mathrm{CH}_{3}\right)_{3}$ & $\begin{array}{l}\text { Reaction 1: acid-base reaction (Hossain et al., } \\
\text { 2004) } \\
\text { Reaction 2: metal complexation (Guilbault } \\
\text { and Billedeau, 1971) } \\
\mathrm{M}^{\mathrm{n}+}+\mathrm{x} \mathrm{N}^{\mathrm{N}}\left(\mathrm{CH}_{3}\right)_{3} \rightarrow\left[\mathrm{M}\left(\mathrm{N}\left(\mathrm{CH}_{3}\right)_{3}\right)_{\mathrm{x}}\right]^{\mathrm{n+}}\end{array}$ & \\
\hline $\mathrm{NH}_{2} \mathrm{OH}$ & $\begin{array}{l}\text { Reaction 3: addition (Jencks, 1959) } \\
\stackrel{\mathrm{R}}{\mathrm{R}^{\prime}}>=\mathrm{O}+\mathrm{NH}_{2} \mathrm{OH} \longrightarrow \stackrel{\mathrm{R}_{\mathrm{R}^{\prime}}}{>}>\mathrm{N}-\mathrm{OH}+\mathrm{H}_{2} \mathrm{O}\end{array}$ & 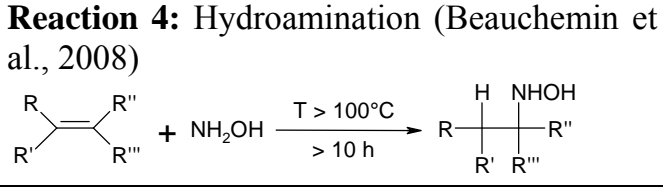 \\
\hline $\mathrm{CF}_{3} \mathrm{COOH}$ & $\begin{array}{l}\text { Reaction 5: acid-base reaction } \\
\mathrm{B}+\mathrm{F}_{3} \mathrm{C}-\mathrm{OH}_{\mathrm{OH}}^{\mathrm{O}} \longrightarrow \mathrm{F}_{3} \mathrm{C}-\mathrm{O}_{\mathrm{O}^{-}}^{\mathrm{O}} \cdot \mathrm{B}^{-} \mathrm{H}^{+}\end{array}$ & \\
\hline $\mathrm{HCl}$ & $\begin{array}{l}\text { Reaction 6: acid-base reaction } \\
\mathrm{B}+\mathrm{HCl} \longrightarrow \mathrm{B}-\mathrm{H}^{+} \cdot \mathrm{Cl}^{-}\end{array}$ & $\begin{array}{l}\text { Reaction 7: addition (Raley et al., 1948) } \\
\text { Reaction 8: (Landini et al., 1974) } \\
\mathrm{R}_{\mathrm{R}} \mathrm{OH}+\mathrm{HCl} \frac{105^{\circ} \mathrm{C} / 30 \mathrm{~h}}{\text { catalyst }} \mathrm{R}-\mathrm{Cl}+\mathrm{H}_{2} \mathrm{O}\end{array}$ \\
\hline $\mathrm{O}_{3}$ & $\begin{array}{l}\text { Reaction 9: ozonolysis (Horie and Moortgat, } \\
\text { 1998) } \\
\left.\mathrm{R}_{\mathrm{R}}^{\mathrm{R}}\right\rangle=\left\langle_{\mathrm{R}^{\prime \prime \prime}}^{\mathrm{R}^{\prime \prime}}+\mathrm{O}_{3} \longrightarrow \mathrm{R}^{\prime}{ }^{\mathrm{R}}\right\rangle \mathrm{O}+\begin{array}{c}\text { Criegee } \\
\text { intermediates }\end{array}\end{array}$ & 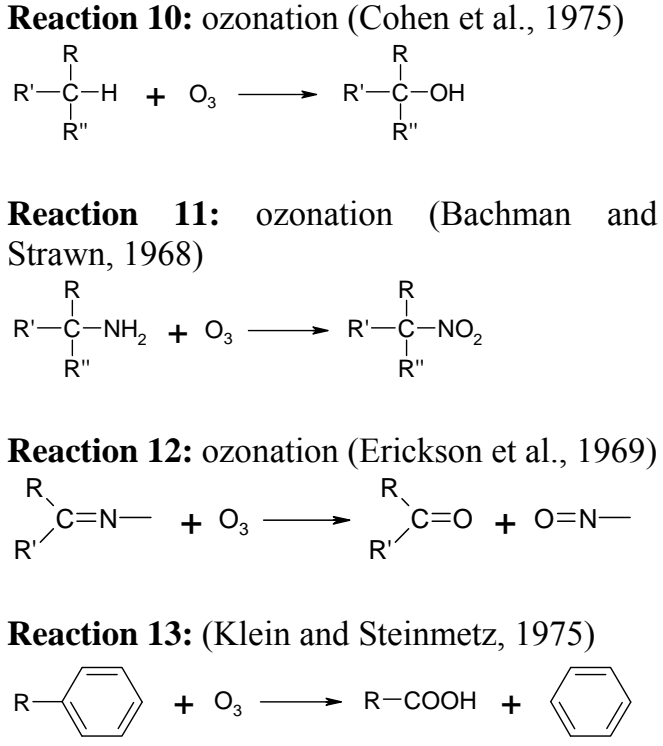 \\
\hline
\end{tabular}


Table 3: Description of sampling sites, including average temperature and humidity during the sampling period.

\begin{tabular}{|l|l|c|c|}
\hline \multicolumn{1}{|c|}{ Sampling site } & \multicolumn{1}{|c|}{ Description of the sampling sites } & $\begin{array}{c}\text { Average } \\
\text { temperature } \\
\text { [ } \mathbf{C} \text { ] }\end{array}$ & $\begin{array}{c}\text { Average relative } \\
\text { humidity } \\
\text { [\% rH] }\end{array}$ \\
\hline $\begin{array}{l}\text { Bus depot 1 } \\
\text { Day 1 }\end{array}$ & $\begin{array}{l}\text { Mechanical yard: repair and maintenance of } \\
\text { buses and trolleybus }\end{array}$ & $22.2 \pm 1.7$ & $33.5 \pm 2.9$ \\
\hline $\begin{array}{l}\text { Bus depot 1 } \\
\text { Day 2 }\end{array}$ & $\begin{array}{l}\text { Mechanical yard: repair and maintenance of } \\
\text { buses and trolleybus }\end{array}$ & $20.8 \pm 0.8$ & $42.7 \pm 3.8$ \\
\hline $\begin{array}{l}\text { Bus depot 2 } \\
\text { Summer - Day 1 }\end{array}$ & $\begin{array}{l}\text { Mechanical yard: repair and maintenance of } \\
\text { buses }\end{array}$ & $23.2 \pm 1.7$ & $42.9 \pm 3.6$ \\
\hline $\begin{array}{l}\text { Bus depot 2 } \\
\text { Summer - Day 2 }\end{array}$ & $\begin{array}{l}\text { Mechanical yard: repair and maintenance of } \\
\text { buses }\end{array}$ & $22.6 \pm 1.2$ & $36.4 \pm 7.6$ \\
\hline $\begin{array}{l}\text { Bus depot 2 } \\
\text { Summer - Night 1 }\end{array}$ & $\begin{array}{l}\text { Nearby a track used by all the buses and } \\
\text { trams to join their respective parking place }\end{array}$ & $23.2 \pm 0.7$ & $53.3 \pm 5.8$ \\
\hline $\begin{array}{l}\text { Bus depot 2 } \\
\text { Summer - Night 2 }\end{array}$ & $\begin{array}{l}\text { Nearby a track used by all the buses and } \\
\text { trams to join their respective parking place }\end{array}$ & $21.4 \pm 0.6$ & $34.7 \pm 3.6$ \\
\hline $\begin{array}{l}\text { Bus depot 2 } \\
\text { Winter - Day 1 }\end{array}$ & $\begin{array}{l}\text { Mechanical yard: repair and maintenance of } \\
\text { buses }\end{array}$ & $21.0 \pm 0.2$ & $40.2 \pm 3.6$ \\
\hline $\begin{array}{l}\text { Bus depot 2 } \\
\text { Winter - Day 2 }\end{array}$ & $\begin{array}{l}\text { Mechanical yard: repair and maintenance of } \\
\text { buses }\end{array}$ & $20.8 \pm 0.6$ & $34.7 \pm 2.9$ \\
\hline $\begin{array}{l}\text { Bus depot 3 } \\
\text { Day 1 }\end{array}$ & $\begin{array}{l}\text { Mechanical yard: repair and maintenance of } \\
\text { buses and trolleybus }\end{array}$ & $24.9 \pm 1.8$ & $29.9 \pm 7.3$ \\
\hline $\begin{array}{l}\text { Bus depot 3 } \\
\text { Day 2 }\end{array}$ & $\begin{array}{l}\text { Mechanical yard: repair and maintenance of } \\
\text { buses and trolleybus }\end{array}$ & $24.1 \pm 1.2$ & $26.4 \pm 5.1$ \\
\hline $\begin{array}{l}\text { Bus depot 3 } \\
\text { Night 1 }\end{array}$ & $\begin{array}{l}\text { Maintenance yard: cleaning and fuel filling } \\
\text { of buses and trolleybus }\end{array}$ & $21.3 \pm 1.9$ & $43.7 \pm 8.2$ \\
\hline $\begin{array}{l}\text { Bus depot 3 } \\
\text { Night 2 }\end{array}$ & $\begin{array}{l}\text { Maintenance yard: cleaning and fuel filling } \\
\text { of buses and trolleybus }\end{array}$ & $19.5 \pm 2.5$ & $33.8 \pm 11.5$ \\
\hline
\end{tabular}


Table 4: Titration experiments using the Knudsen flow reactor. Unit: \% of a complete molecular monolayer.

\begin{tabular}{|c|c|c|c|c|c|}
\hline & $\mathrm{N}\left(\mathrm{CH}_{3}\right)_{3}$ & $\mathrm{NH}_{2} \mathrm{OH}$ & $\mathrm{CF}_{3} \mathrm{COOH}$ & $\mathrm{HCl}$ & $\mathbf{O}_{3}$ \\
\hline $\begin{array}{l}\text { monolayer } \\
\text { ( } \pm \text { uncertainty) }\end{array}$ & $\begin{array}{l}3.6( \pm 0.2) \cdot 10^{14} \\
{\left[\text { molecule } / \mathrm{cm}^{2}\right]}\end{array}$ & $\begin{array}{l}7.9( \pm 0.5) \cdot 10^{14} \\
{\left[\mathrm{molecule} / \mathrm{cm}^{2}\right]}\end{array}$ & $\begin{array}{l}4.0( \pm 0.3) \cdot 10^{14} \\
{\left[\text { molecule } / \mathrm{cm}^{2}\right]}\end{array}$ & $\begin{array}{l}8.6( \pm 0.5) \cdot 10^{14} \\
{\left[\text { molecule } / \mathrm{cm}^{2}\right]}\end{array}$ & $\begin{array}{l}7.4( \pm 0.5) \cdot 10^{14} \\
{\left[\text { molecule } / \mathrm{cm}^{2}\right]}\end{array}$ \\
\hline limonene SOA & $3.6 \%$ & $493.7 \%$ & $5.3 \%$ & not detected & $7.7 \%$ \\
\hline $\mathrm{Pb}\left(\mathrm{NO}_{3}\right)_{2}$ & $4.4 \%$ & $202.5 \%$ & $2.1 \%$ & $23.3 \%$ & not detected \\
\hline $\mathrm{Cd}\left(\mathrm{NO}_{3}\right)_{2}$ & $2.0 \%$ & $797.5 \%$ & $5.5 \%$ & $104.7 \%$ & not detected \\
\hline SRM 2975 & $14.7 \%$ & $189.9 \%$ & not detected & $0.3 \%$ & $1.2 \%$ \\
\hline $\begin{array}{l}\text { Bus depot } 1 \\
\text { Day } 1\end{array}$ & not available & not available & not available & not available & not available \\
\hline $\begin{array}{l}\text { Bus depot } 1 \\
\text { Day } 2\end{array}$ & not available & not available & not available & not available & not available \\
\hline $\begin{array}{l}\text { Bus depot } 2 \\
\text { Summer - Day } 1\end{array}$ & $1.9 \%$ & $148.1 \%$ & $50.8 \%$ & $55.2 \%$ & $16.8 \%$ \\
\hline $\begin{array}{l}\text { Bus depot } 2 \\
\text { Summer - Day } 2\end{array}$ & $18.6 \%$ & $646.8 \%$ & $59.0 \%$ & $87.7 \%$ & $38.9 \%$ \\
\hline $\begin{array}{l}\text { Bus depot } 2 \\
\text { Summer - Night } 1\end{array}$ & $20.0 \%$ & $384.8 \%$ & $131.0 \%$ & $187.2 \%$ & $33.6 \%$ \\
\hline $\begin{array}{l}\text { Bus depot } 2 \\
\text { Summer - Night } 2\end{array}$ & $0.7 \%$ & not available & $13.4 \%$ & $9.3 \%$ & $3.1 \%$ \\
\hline $\begin{array}{l}\text { Bus depot } 2 \\
\text { Winter - Day } 1 \\
\end{array}$ & not detected & $42.3 \%$ & $11.0 \%$ & $9.7 \%$ & $362.2 \%$ \\
\hline $\begin{array}{l}\text { Bus depot } 2 \\
\text { Winter - Day } 2\end{array}$ & not detected & $29.2 \%$ & $51.0 \%$ & $40.3 \%$ & $535.1 \%$ \\
\hline $\begin{array}{l}\text { Bus depot } 3 \\
\text { Day } 1\end{array}$ & $4.2 \%$ & $29.9 \%$ & $10.7 \%$ & $16.3 \%$ & $6.6 \%$ \\
\hline $\begin{array}{l}\text { Bus depot } 3 \\
\text { Day } 2\end{array}$ & $7.8 \%$ & $25.7 \%$ & $6.7 \%$ & $13.8 \%$ & $7.0 \%$ \\
\hline $\begin{array}{l}\text { Bus depot } 3 \\
\text { Night } 1 \\
\end{array}$ & $12.5 \%$ & $87.3 \%$ & $62.8 \%$ & $67.7 \%$ & $3.6 \%$ \\
\hline $\begin{array}{l}\text { Bus depot } 3 \\
\text { Night } 2\end{array}$ & $9.9 \%$ & $30.3 \%$ & $3.0 \%$ & $9.5 \%$ & not detected \\
\hline
\end{tabular}


Table 5: Uptake coefficient $\gamma_{0}$ of heterogeneous chemical reactions between probe gases and laboratory-generated aerosols in the Knudsen flow reactor, based on the geometric surface area of the sample.

\begin{tabular}{|l|c|c|c|c|c|}
\hline & $\mathbf{N}\left(\mathbf{C H}_{3}\right)_{3}$ & $\mathbf{N H}_{2} \mathbf{O H}$ & $\mathbf{C F} \mathbf{C O O H}$ & $\mathbf{H C l}$ & $\mathbf{O}_{3}$ \\
\hline limonene SOA & $2.5( \pm 0.1) \cdot 10^{-4}$ & $2.4( \pm 0.4) \cdot 10^{-3}$ & $7.1( \pm 0.6) \cdot 10^{-5}$ & not detected & $4.7( \pm 0.4) \cdot 10^{-4}$ \\
\hline $\mathbf{P b}\left(\mathbf{N O}_{3}\right)_{2}$ & $3.5( \pm 0.2) \cdot 10^{-4}$ & $2.0( \pm 0.3) \cdot 10^{-4}$ & $2.9( \pm 0.2) \cdot 10^{-3}$ & $5.8( \pm 0.2) \cdot 10^{-2}$ & not detected \\
\hline $\mathbf{C d}\left(\mathbf{N O}_{3}\right)_{2}$ & $9.9( \pm 0.6) \cdot 10^{-5}$ & $2.0( \pm 0.3) \cdot 10^{-4}$ & $1.8( \pm 0.1) \cdot 10^{-3}$ & $6.3( \pm 0.2) \cdot 10^{-4}$ & not detected \\
\hline SRM 2975 & $2.4( \pm 0.1) \cdot 10^{-2}$ & $1.5( \pm 0.3) \cdot 10^{-2}$ & not detected & $2.9( \pm 0.1) \cdot 10^{-3}$ & $5.8( \pm 0.5) \cdot 10^{-4}$ \\
\hline
\end{tabular}

Values in bracket: standard deviation of duplicates. 
Table 6: Uptake coefficient $\gamma_{0}$ of heterogeneous chemical reactions between probe gases and aerosols collected in bus depots, based on the geometric surface area of the sample.

\begin{tabular}{|c|c|c|c|c|c|}
\hline & $\mathrm{N}\left(\mathrm{CH}_{3}\right)_{3}$ & $\mathrm{NH}_{2} \mathrm{OH}$ & $\mathrm{CF}_{3} \mathrm{COOH}$ & $\mathrm{HCl}$ & $\mathbf{O}_{3}$ \\
\hline $\begin{array}{l}\text { Bus depot } 1 \\
\text { Day } 1\end{array}$ & $7.6( \pm 1.1) \cdot 10^{-5}$ & $1.9( \pm 0.4) \cdot 10^{-4}$ & $7.8( \pm 1.0) \cdot 10^{-5}$ & $1.1( \pm 0.2) \cdot 10^{-4}$ & $2.0( \pm 0.1) \cdot 10^{-3}$ \\
\hline $\begin{array}{l}\text { Bus depot } 1 \\
\text { Day } 2\end{array}$ & not detected & $2.3( \pm 0.7) \cdot 10^{-4}$ & $1.0( \pm 0.1) \cdot 10^{-4}$ & $1.7( \pm 0.2) \cdot 10^{-4}$ & $2.6( \pm 0.2) \cdot 10^{-3}$ \\
\hline $\begin{array}{l}\text { Bus depot } 2 \\
\text { Summer - Day } 1\end{array}$ & $7.4( \pm 0.4) \cdot 10^{-5}$ & $2.4( \pm 0.2) \cdot 10^{-4}$ & $2.0( \pm 0.4) \cdot 10^{-4}$ & $4.3( \pm 0.3) \cdot 10^{-4}$ & $1.0( \pm 0.1) \cdot 10^{-3}$ \\
\hline $\begin{array}{l}\text { Bus depot } 2 \\
\text { Summer - Day } 2\end{array}$ & $9.1( \pm 0.3) \cdot 10^{-5}$ & $4.6( \pm 0.1) \cdot 10^{-4}$ & $2.0( \pm 0.1) \cdot 10^{-4}$ & $4.3( \pm 0.1) \cdot 10^{-4}$ & $1.5( \pm 0.2) \cdot 10^{-3}$ \\
\hline $\begin{array}{l}\text { Bus depot } 2 \\
\text { Summer - Night } 1\end{array}$ & $1.0( \pm 0.1) \cdot 10^{-4}$ & $3.3( \pm 0.1) \cdot 10^{-4}$ & $4.1( \pm 0.4) \cdot 10^{-4}$ & $1.6( \pm 0.1) \cdot 10^{-3}$ & $1.2( \pm 0.1) \cdot 10^{-3}$ \\
\hline $\begin{array}{l}\text { Bus depot } 2 \\
\text { Summer - Night } 2\end{array}$ & $9.4( \pm 0.3) \cdot 10^{-5}$ & not available & $1.0( \pm 0.1) \cdot 10^{-4}$ & $1.5( \pm 0.1) \cdot 10^{-4}$ & $7.0( \pm 0.7) \cdot 10^{-4}$ \\
\hline $\begin{array}{l}\text { Bus depot } 2 \\
\text { Winter - Day } 1 \\
\end{array}$ & not detected & $7.5( \pm 1.5) \cdot 10^{-4}$ & $4.2( \pm 0.6) \cdot 10^{-3}$ & $4.5( \pm 0.8) \cdot 10^{-3}$ & $3.6( \pm 0.3) \cdot 10^{-3}$ \\
\hline $\begin{array}{l}\text { Bus depot } 2 \\
\text { Winter - Day } 2\end{array}$ & not detected & $1.5( \pm 0.1) \cdot 10^{-3}$ & $1.4( \pm 0.1) \cdot 10^{-2}$ & $1.8( \pm 0.3) \cdot 10^{-2}$ & $3.3( \pm 0.5) \cdot 10^{-3}$ \\
\hline $\begin{array}{l}\text { Bus depot } 3 \\
\text { Day } 1\end{array}$ & $5.2( \pm 0.1) \cdot 10^{-5}$ & $3.0( \pm 0.4) \cdot 10^{-4}$ & $9.7( \pm 1.1) \cdot 10^{-5}$ & $1.4( \pm 0.1) \cdot 10^{-4}$ & $9.8( \pm 1.0) \cdot 10^{-4}$ \\
\hline $\begin{array}{l}\text { Bus depot } 3 \\
\text { Day } 2\end{array}$ & $7.9( \pm 0.7) \cdot 10^{-5}$ & $1.4( \pm 0.1) \cdot 10^{-4}$ & $7.3( \pm 0.1) \cdot 10^{-5}$ & $9.2( \pm 0.3) \cdot 10^{-5}$ & $1.7( \pm 0.1) \cdot 10^{-3}$ \\
\hline $\begin{array}{l}\text { Bus depot } 3 \\
\text { Night } 1 \\
\end{array}$ & $6.2( \pm 0.5) \cdot 10^{-5}$ & $2.0( \pm 0.6) \cdot 10^{-4}$ & $1.2( \pm 0.1) \cdot 10^{-4}$ & $1.6( \pm 0.1) \cdot 10^{-4}$ & $9.4( \pm 0.9) \cdot 10^{-4}$ \\
\hline $\begin{array}{l}\text { Bus depot } 3 \\
\text { Night } 2\end{array}$ & $1.1( \pm 0.1) \cdot 10^{-4}$ & $1.4( \pm 0.3) \cdot 10^{-4}$ & $5.0( \pm 0.2) \cdot 10^{-5}$ & $5.4( \pm 0.1) \cdot 10^{-5}$ & not detected \\
\hline
\end{tabular}

Values in bracket: standard deviation of duplicates. 
Figure 1

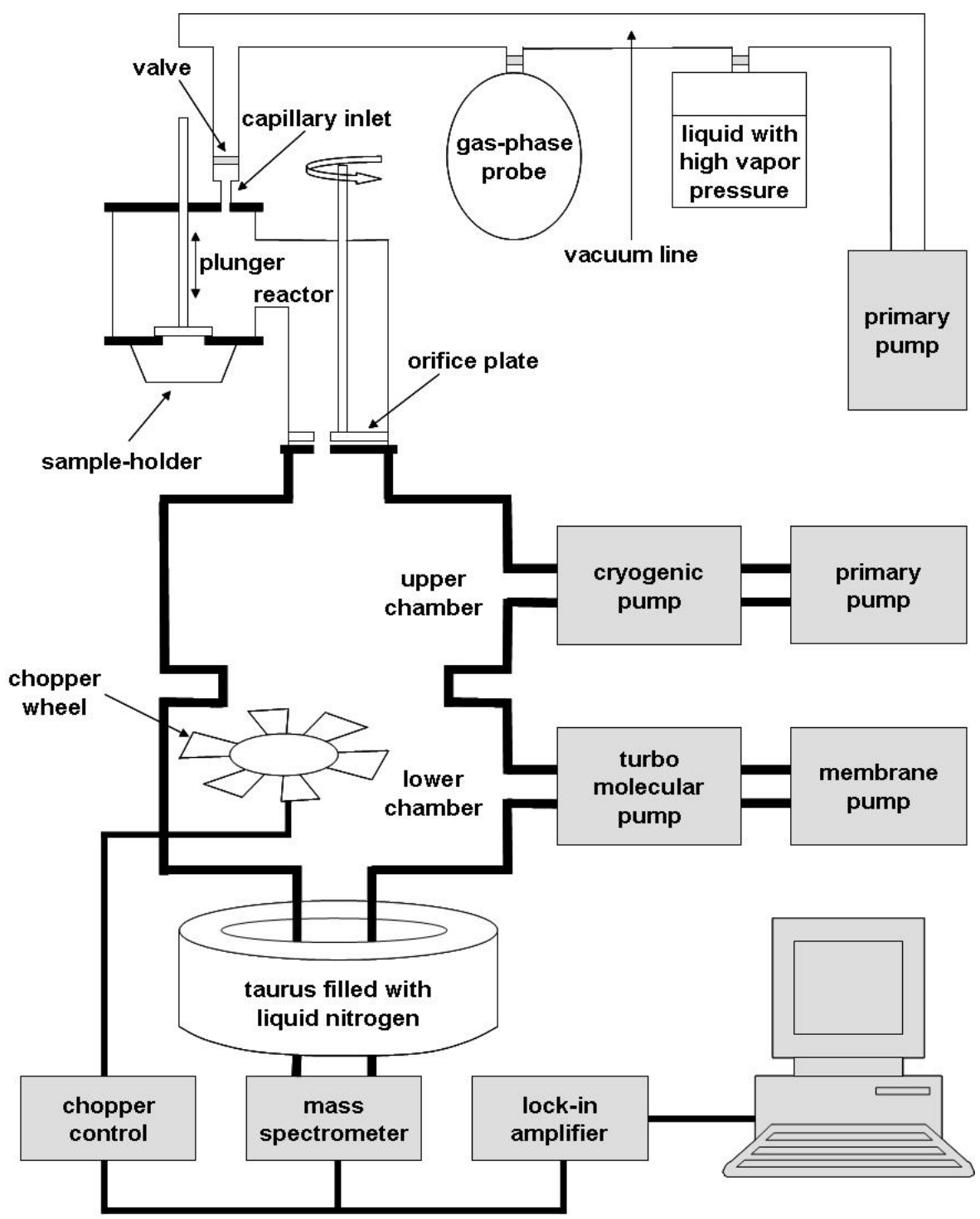


Figure 2

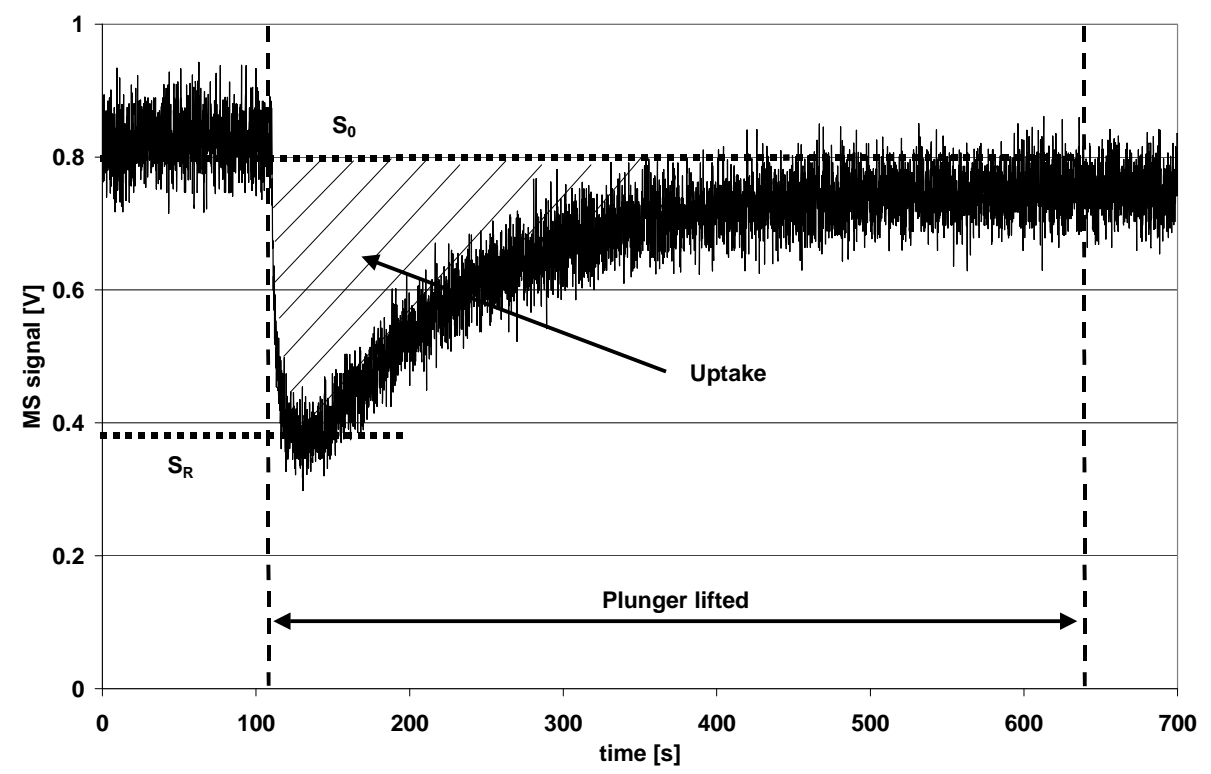


Figure 3

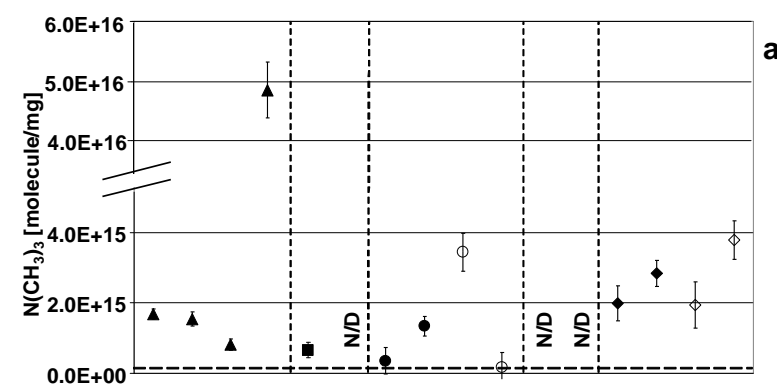

a)
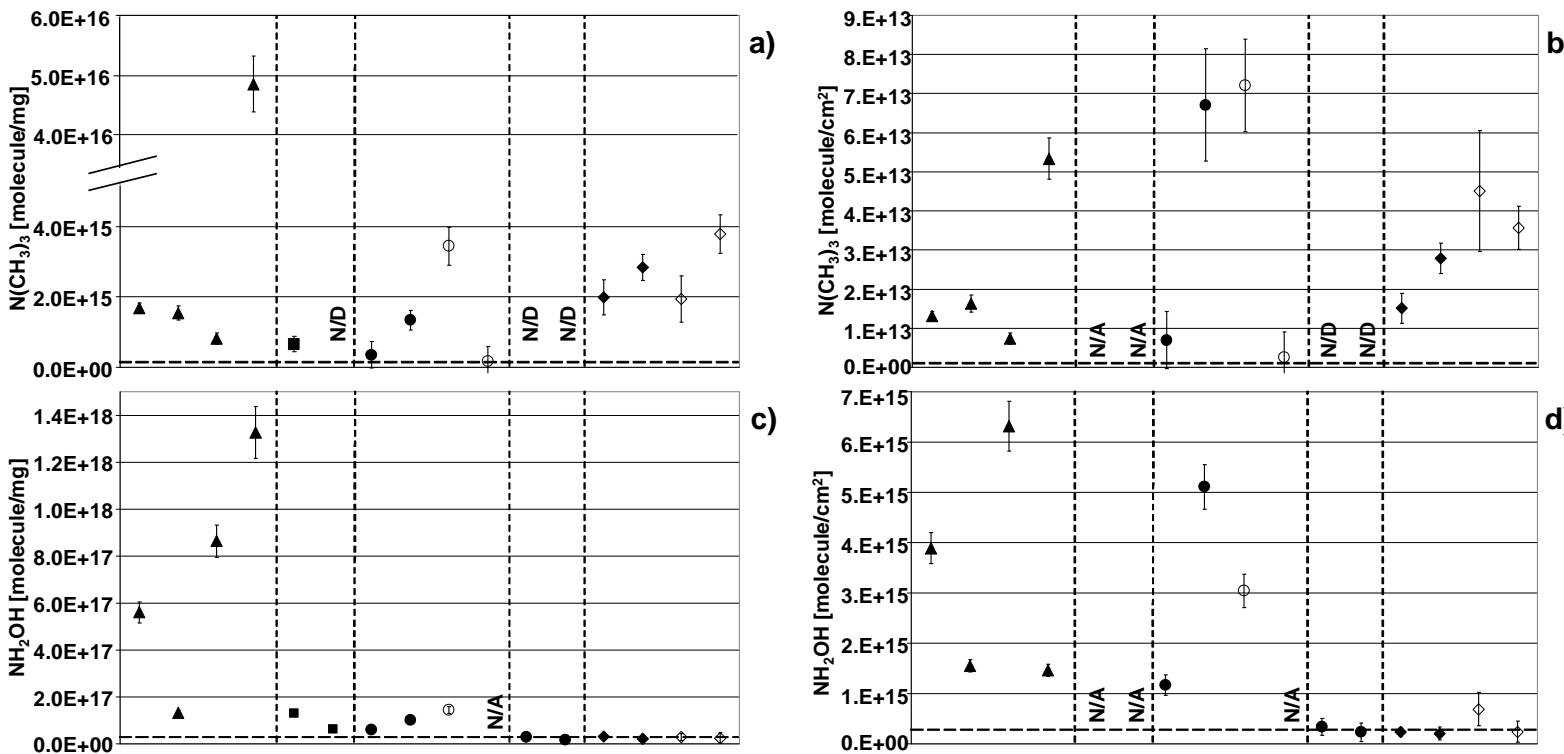

c)
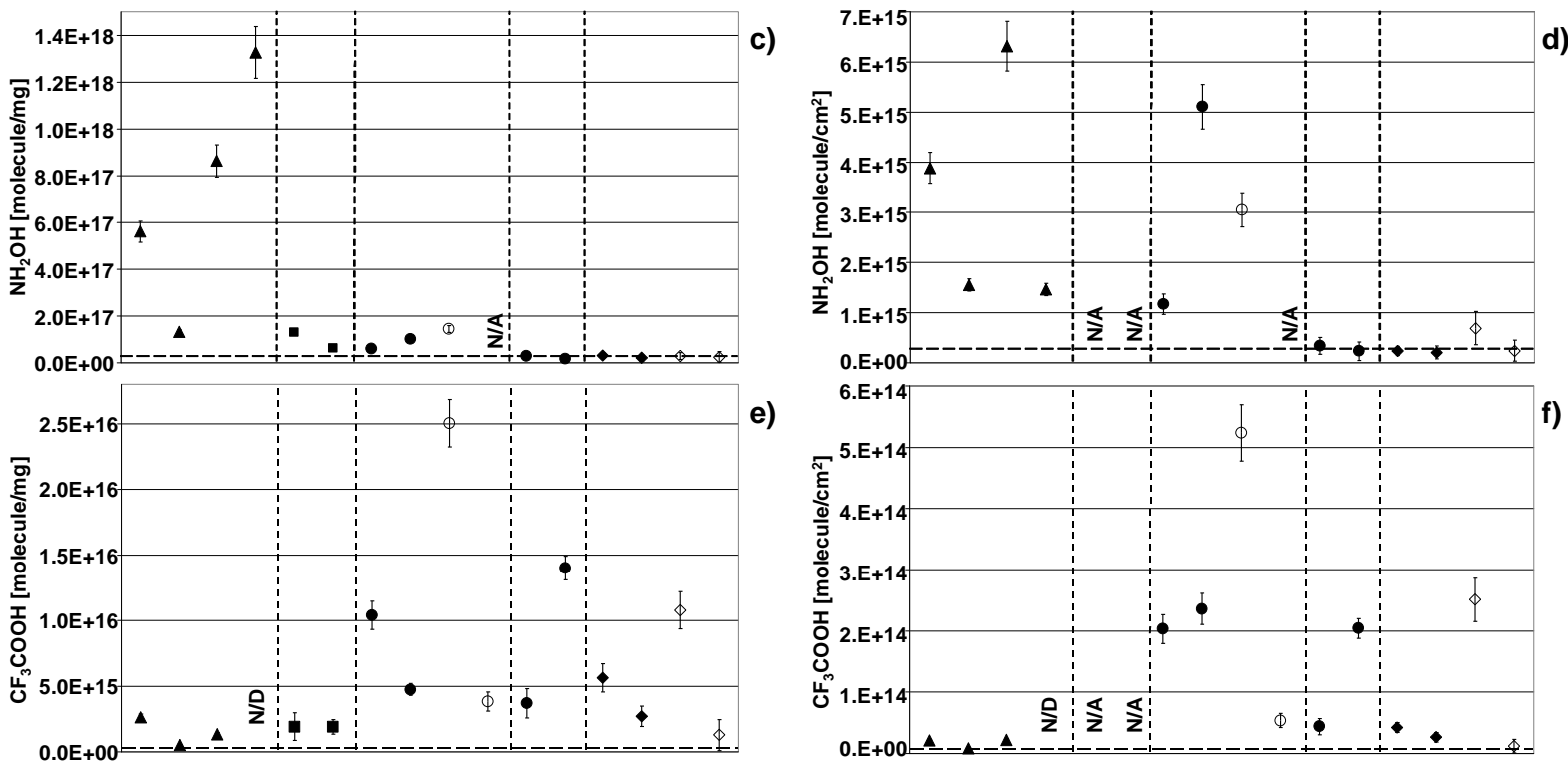

e)
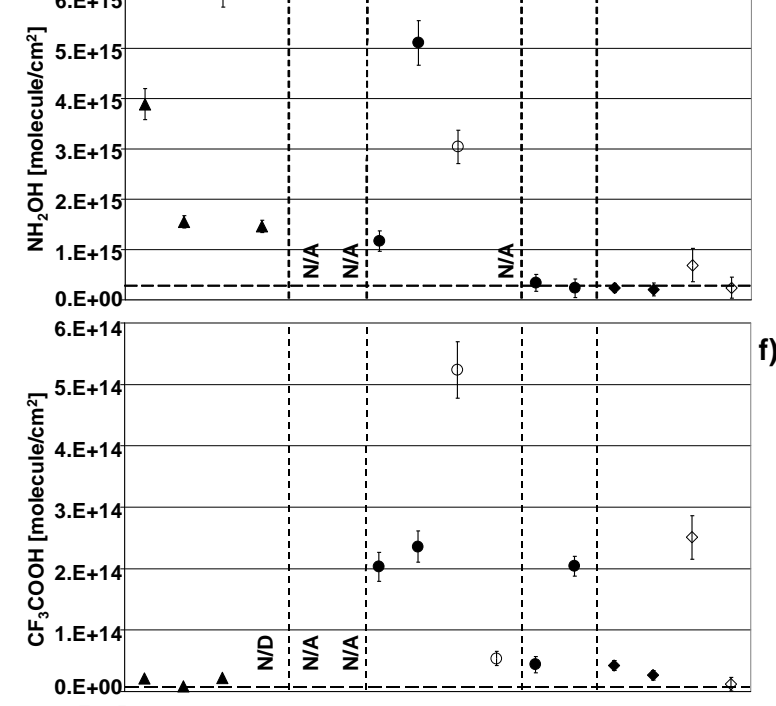

g)

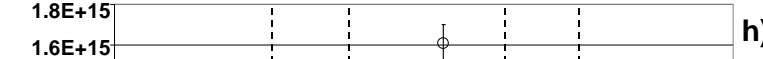

b)
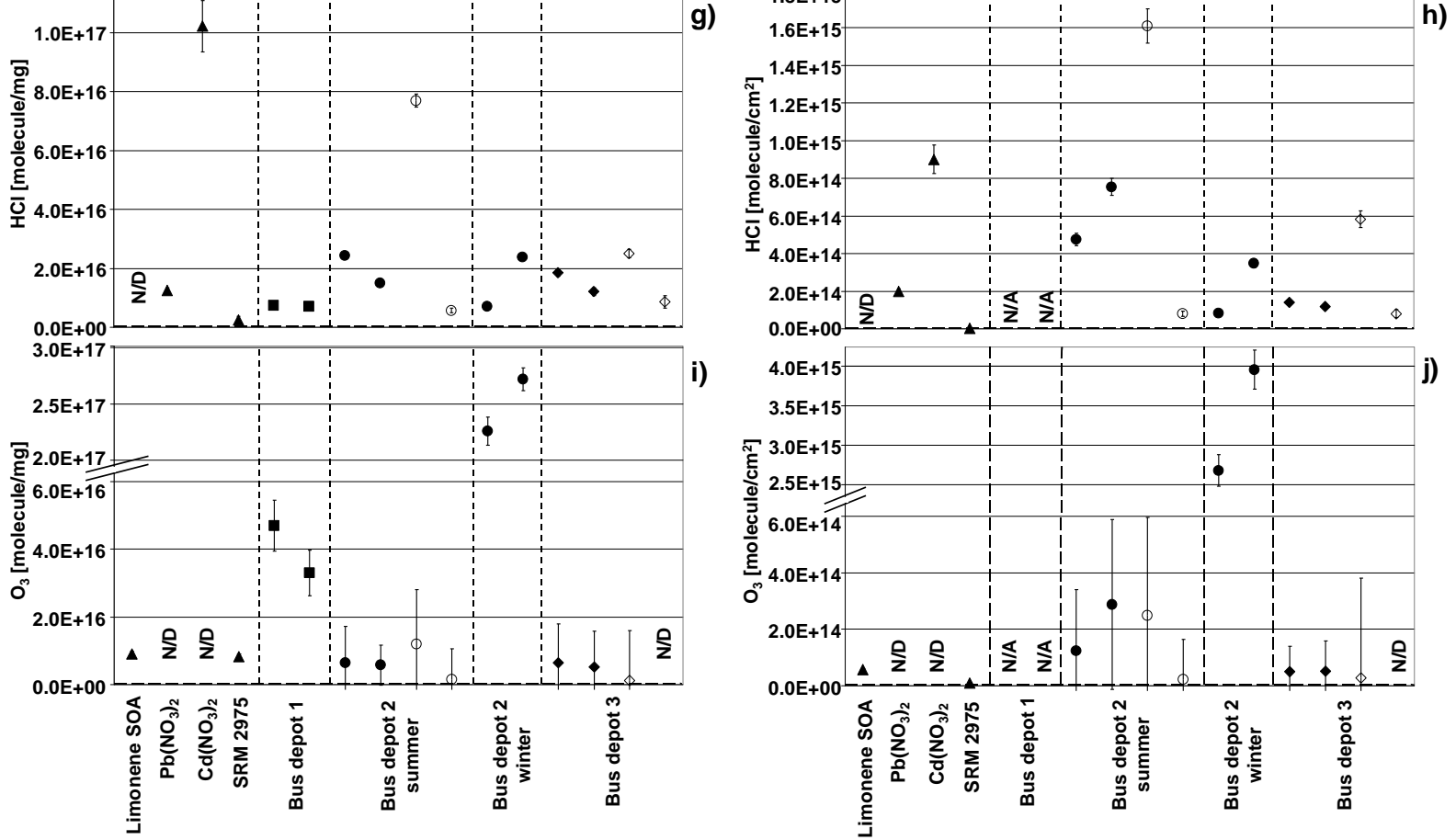
Figure 4

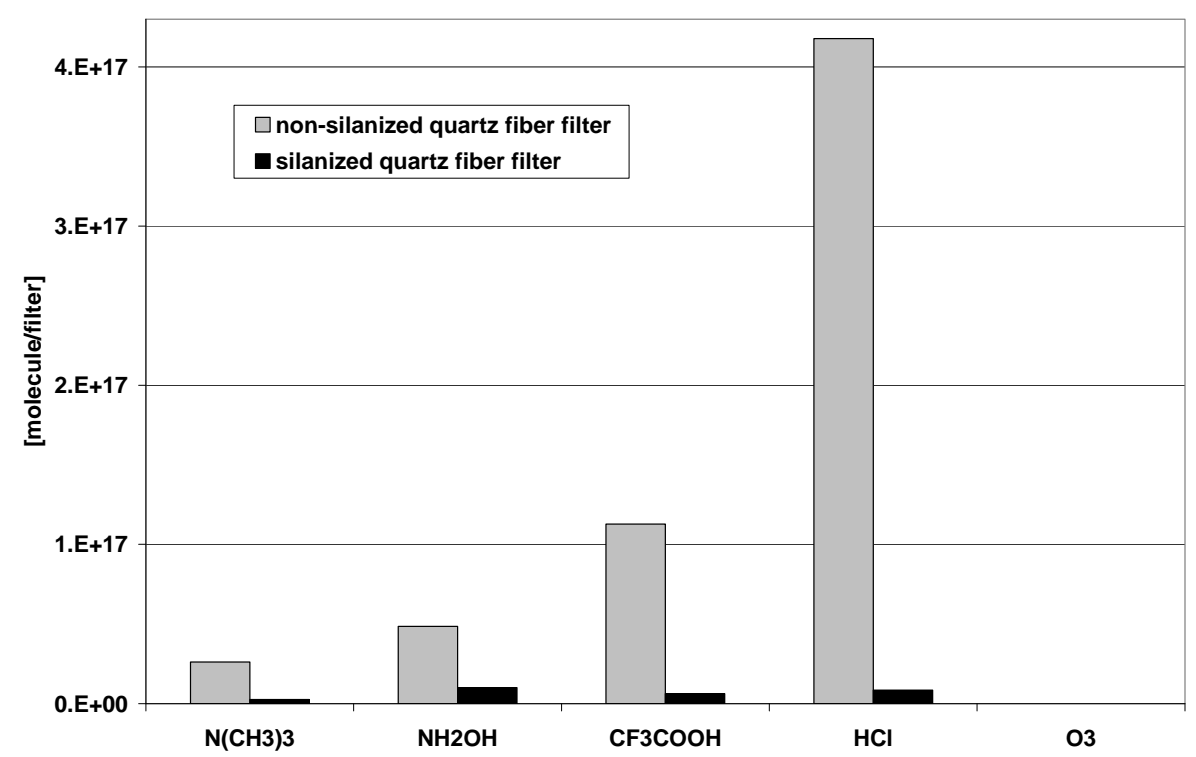

